BROOKIIAVEN NATIONAL LABORATORY DEVELOPING COUNTRIFS ENERGY PROGRAM

\title{
LESS DEVELOPED COUNTRIES \\ ENERGY SYSTEM NETWORK SIMULATOR \\ LDC-ESNS: \\ A Brief Description
}

Ann Reisman and Robert Malone

April 1978

POLICY ANALYSIS DIVISION

NATIONAL CENTER FOR ANALYSIS OF ENERGY SYSTEMS

BKOUKHAVEN NATIONAL LABORATORY

UPTON, NEW YORK 11973

Prepared for the

U.S. Department of Energy International Energy Development Program 


\section{DISCLAIMER}

This report was prepared as an account of work sponsored by an agency of the United States Government. Neither the United States Government nor any agency Thereof, nor any of their employees, makes any warranty, express or implied, or assumes any legal liability or responsibility for the accuracy, completeness, or usefulness of any information, apparatus, product, or process disclosed, or represents that its use would not infringe privately owned rights. Reference herein to any specific commercial product, process, or service by trade name, trademark, manufacturer, or otherwise does not necessarily constitute or imply its endorsement, recommendation, or favoring by the United States Government or any agency thereof. The views and opinions of authors expressed herein do not necessarily state or reflect those of the United States Government or any agency thereof. 


\section{DISCLAIMER}

Portions of this document may be illegible in electronic image products. Images are produced from the best available original document. 


\title{
LESS DEVELOPED COUNTRIES ENERGY SYSTEM NETWORK SIMULATOR LDC-ESNS: A BRIEF DESCRIPTION
}

Ann Reisman and Robert Malone

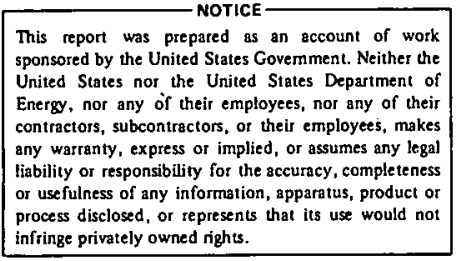

infringe privately owned rights.

\section{April 1978}

\author{
POLICY ANALYSIS DIVISION \\ NATIONAL CENTER FOR ANALYSIS OF ENERGY SYSTEMS \\ BROOKHAVEN NATIONAL LABORATORY \\ UPTON, NEW YORK 11973
}

PREPARED FOR THE

U.S. DEPARTMENT OF ENERGY INTERNATIONAL ENERGY DEVELOPMENT PROGRAM

UNDER CONTRACT NO. EY-76-C-02-0016 


\section{NOTICE}

This report was prepared as an account of work sponsored by the United States Government. Neither the United States nor the United States Department of Energy (DOE), nor any of their employees, nor any of their contractors, subcontractors, or their employees, makes any warranty, express or implied, or assumes any legal liability or responsibility for the accuracy, completeness or usefulness of any information, apparatus, product or process disclosed, or represents that its use would not infringe privately owned rights.

Printed in the United States of America Available from

National Technical Information Service

U.S. Department of Commerce

5285 Port Royal Road

Springfield, VA 22161

: Price: Printed Copy $\$ 6.00$; Microfiche $\$ 3.00$

June 1978

520 copies 


\section{ABSTRACT}

Prepared for the Brookhaven National Laboratory Developing Countries Energy Program, this report describes the Less Deve1oped Countries Energy System Network Simulator (LDC-ESNS), a tool which provides a quantitative representation of the energy system of an LDC. The network structure of the energy. supply and demand system, the model inputs and outputs, and the possible uses of the model for analysis are described. 


\section{ACKNOWLEDGEMENTS}

We would like to thank Philip Palmedo for his comments and suggestions on the first draft of this paper, Vinod Mubayi and Robert Nathans for their help in defining a demand structure suitable for analysis of LDCs, Mike Owens for assistance in assembling of computer input files, and Joseph Podhaiski for his aid in working with the structure of the computer code.

In addition, our thanks go to Elizabeth Seubert, who patiently typed the manuscript through the authors' several revisions, and the Brookhaven Graphic Arts Department, especially Emil Caiazza, who produced the illustrations. 


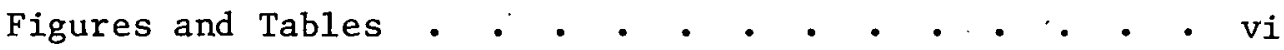
Introduction $\quad \cdot \quad \cdot \quad \cdot \quad \cdot \quad \cdot \quad \cdot \quad \cdot \quad \cdot \quad \cdot \quad \cdot \quad \cdot \quad \cdot \quad \cdot \quad \cdot 1$

I. General Description . . . . . . . . . . . 2
A. Inputs
1. Reference Energy System
. 2
2. Energy Demand
3. Efficiencies
4. Market Allocation . • • . . • . . 9
5. Other Parameters . . • . . . . 9
B. Calculations . . . . . . . . • . . 9
C. Output • • • • • • • • • • • 12
D. Composite RES Diagram • • • • • • • • • 12

II. Perturbations . • • • • • • • • • • • 13 


\section{$\underline{\text { Figures }}$}

1. LDC Reference Energy System (Illustrative) . . . . . 3

2. Reference Energy System for India . • • • • • . 4

3. Energy Flow Calculations in LDC-ESNS . • • • • • 7

4. Energy Balance for Process . . . . . . . • . 8

5. Inverted Listing Segment - India . • • • . • • . 14

6. Production Run Listing - India . • • • . . . . 17

7. Composite RES Diagram . . . . . . . . . . . 32

\section{Tables}

I. Energy Supply and Activity Categories . • . • . 5

II. Demand Sector Breakdown . • • • • • • • • • 5

III. Optional Parameters for LDC-ESNS . . . . . . . . 10

IV. List of Current Processes. . . . . • . . . . . 54 


\section{NTRODUCTION}

LDC-ESNS is a framework which describes quantitatively the flow of energy within a country from resources (including imports), through the processes which refine it, convert it from one form to another, transport it, and finally deliver it to the consumers of the final product. In addition, the monetary cost of each pathway, as well as its environmental impact as measured by the air and water residuals generated by the energy flows, can be specified and summed over all pathways to provide a total system view. The structure of the model is designed to apply to the energy system of developing countries.(1).

The framework is designed to be used in the following way: A projection is made of the energy services or fuels to be provided in some future reference year. By energy services are meant the levels of energy-using activities, such as vehicle-miles traveled or amount of irrigation pumping to be performed. Assumptions are then made about the fuels and technologies used to supply these energy services. (Alternatively one can start with estimates of fuel requirements.) . Engineering economic assumptions are then made about the energy supp1y and conversion processes within the energy system so that a complete supply and conversion picture is assembled for the future year. The : model then can be used to analyze the implications--in terms of resource , consumption, costs, capital requirements, etc.--of alternative resource and technological assumptions. For example, one can examine the impact on resource consumption of a change in the level of energy services, or the impact on the environment of increases in process efficiencies at various points in the system, or the system-wide impacts of the introduction of solar energy technologies.

In one sense the framework should not be considered a "model"--in that there are no decisions made internal to the framework. Allocations of different energy forms or fuels would be specified exogenously. Nonetheless the term model may be applied to the framework in that it is a quantitative representation of a country's (or a region's) energy system. 


\section{GENERAL DESCRIPTION}

\section{A. Inputs}

The input information required to operate LDC-ESNS includes the overall supply and demand structure of the energy system, the magnitude and type of energy demand, the efficiency of each technological process represented, the market allocation of each process and, if available, cost and environmental residual data. The model as currently constructed does not contain a projection component, but depends upon exogenously specified demands.

\section{Reference Energy System}

A diagram which represents graphically the flow of energy within a country for a specific year and fuel/technology mix is known as a Reference Energy System (RES). A schematic RES for developing countries is shown in Figure 1. An RES for India for the year 1972 is shown in Figure 2.

A Reference Energy System is structured with the resource categories displayed on the left-hand side, demand categories on the right, and along the top the activities needed to convert energy to the forms required to satisfy the country's energy demands. Included under each general activity category are the specific technological processes which perform the functions of that activity within the country.

The supply side of the RES is divided into categories as displayed in Table I. All processes which are involved in supplying energy to the final demand can be assigned to a supply-activity category combination and displayed in an RES diagram. 


\section{LDC REFERENCE ENERGY SYSTEM (ILLUSTRATIVE)}

\begin{tabular}{c|c} 
RESOURCE \\
EXTRACTION
\end{tabular}$\left|\begin{array}{c}\text { REFINING } \\
\text { AND } \\
\text { CONVERSION }\end{array}\right|$ TRANSPORT $\mid$ CONVERSION $\left|\begin{array}{c}\text { TRANSMISSION } \\
\text { ANO } \\
\text { OISTRIBUTION }\end{array}\right| \begin{gathered}\text { UTILIZING } \\
\text { DEVICE }\end{gathered} \mid$ END USE

NUCLEAR

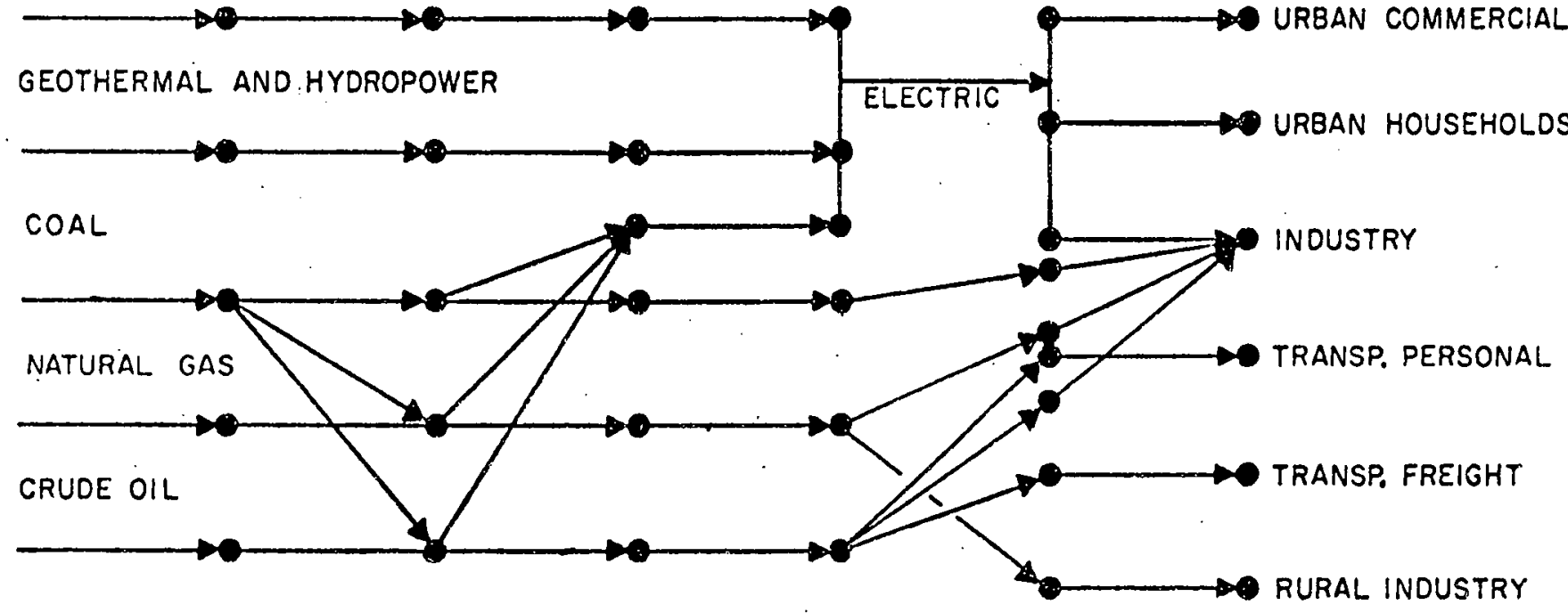

WOOD

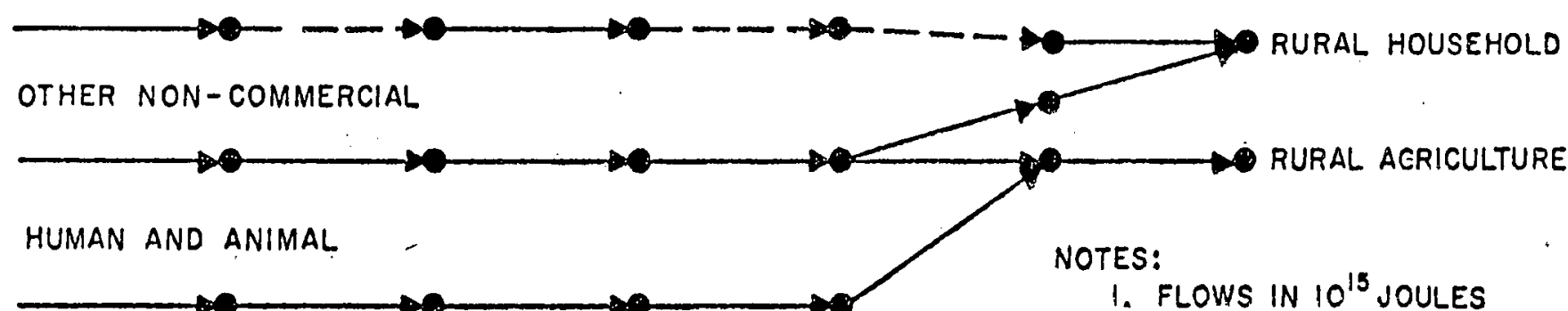

2. SOLID LINE INOICATES REAL PROCESS

3. CONVERSION EFFICIENCIES SHOWN IN PARENTHESIS 


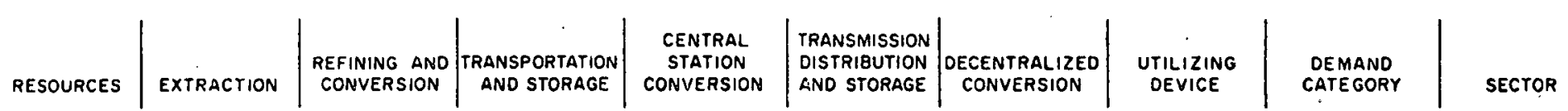

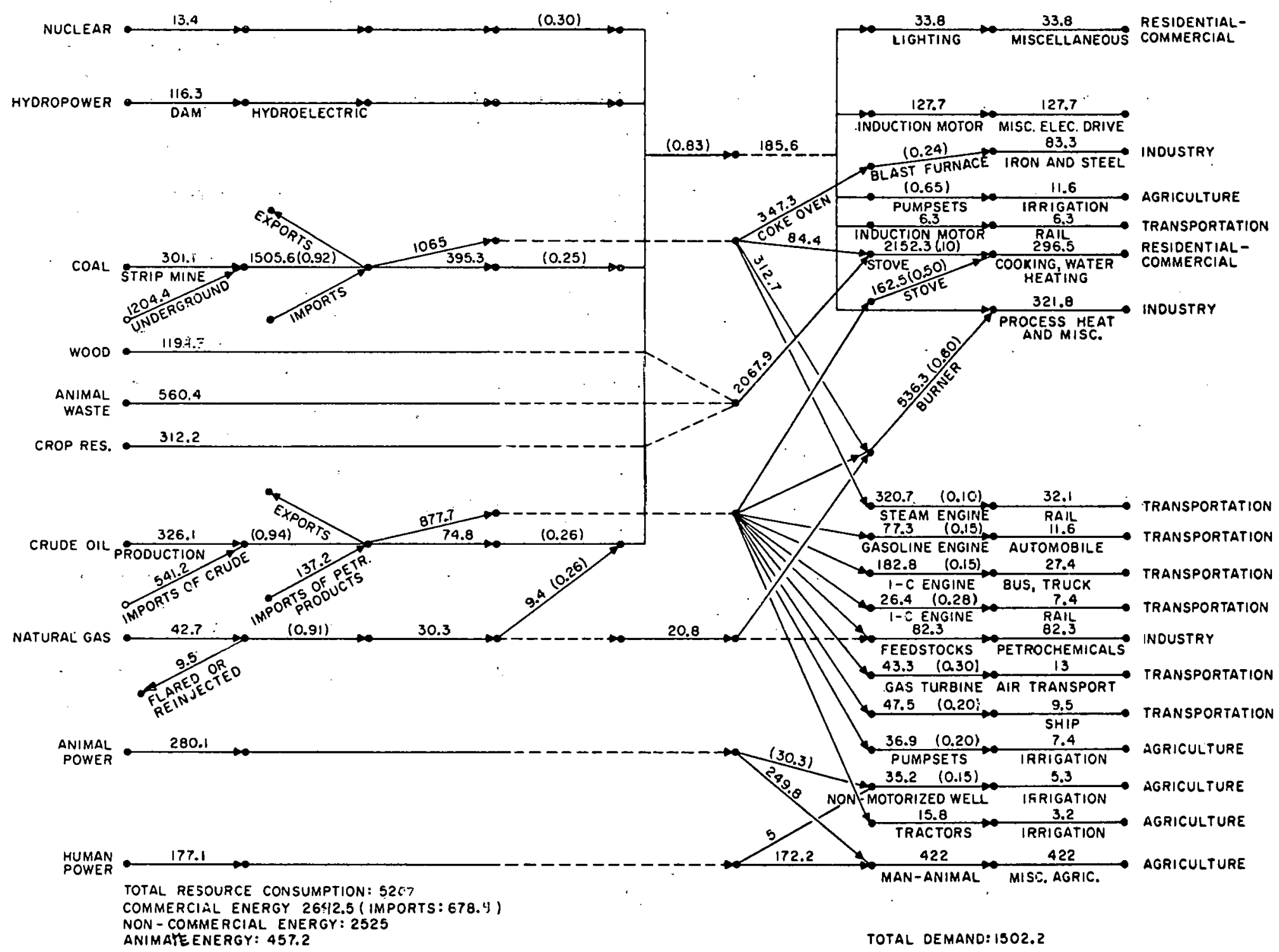

TOTAL DEMAND: 1502.2 
Table I

Energy Supply and Activity Categories

Supply Categories (Energy sources)

I Commercial energy

A. Non-renewable resources

Fossil fuels

Nuclear fuels

B. Renewable resources

Solar-derived energy

C. Imports

II Nón-Commercial energy
A. Wood
B. Animal and Human wastes
C. Crop Residues

III Animate energy
Activity Categories (energy processing)

I Extraction

II Transportation

III Cleaning and Refining

IV Conversion

V Distribution and Transmission

A. Animal and Human muscle power

The demand sectors represented in an RES depend heavily on the quality and disaggregation of the available data. For the developing countries, the demand for energy is broken down into 4 sectors, each with several subsectors, (see Table II). Within each demand, sector and subsector are included the individual end use processes which exist in that country and for which data are available or can be inferred.

\section{Table II}

Demand Sector Breakdown

I Urban Sector

1. Household uses

2. Commercial

II Rural Sector
III Industrial sector

IV Transport Sector

1. Personal

2. Freight

1. Household uses

2. Agriculture

3. Small scale Industry 
The structure of the Reference Energy System for each country is the primary input to the LDC-ESNS model.

\section{Energy Demand}

Demand for energy drives the LDC-ESNS model. The model calculates the level of energy resources and imports required to satisfy a specified mix of demand types.

Demand for energy can be quantified for input, into LDC-ESNS in three ways (see Figure 3).

a. Direct Fuel Consumption (DFC) - the amount of fuel ( $x$ ) in joules delivered to a particular end use category,

b. Basic energy demand (BED) - the amount of energy in joules which represents the useful energy required by the particular demand category,

c. Measure of demand activity (measure) - The level of demand requirement expressed in units of activity i.e., passenger-miles traveled for automobiles.

Demand expressed initially as basic energy demand or measure is converted within the model to direct fuel consumption by the use of numbers to represent the efficiency of end use (see Section IB-Calculations).

\section{Efficiencies}

Efficiency can be represented in LDC-ESNS in three different ways: primary efficiency, relative effectiveness and energy demand per meásure.

Primary efficiency, used in all supply processes, is defined as the ratio of useful energy out of the process to primary energy deliyered to the process. Fuel of a type other than the primary fuel which may also be required by the process, called ancillary fuel, is not included in the calculation of the primary efficiency (see Figure 4). 
ENERGY FLOW CALCULATIONS IN LDC-ESNS

ALL ENERGY FLOWS NORMALIZED TO $10^{15}$ JOULE $=1 \mathrm{PJ}$

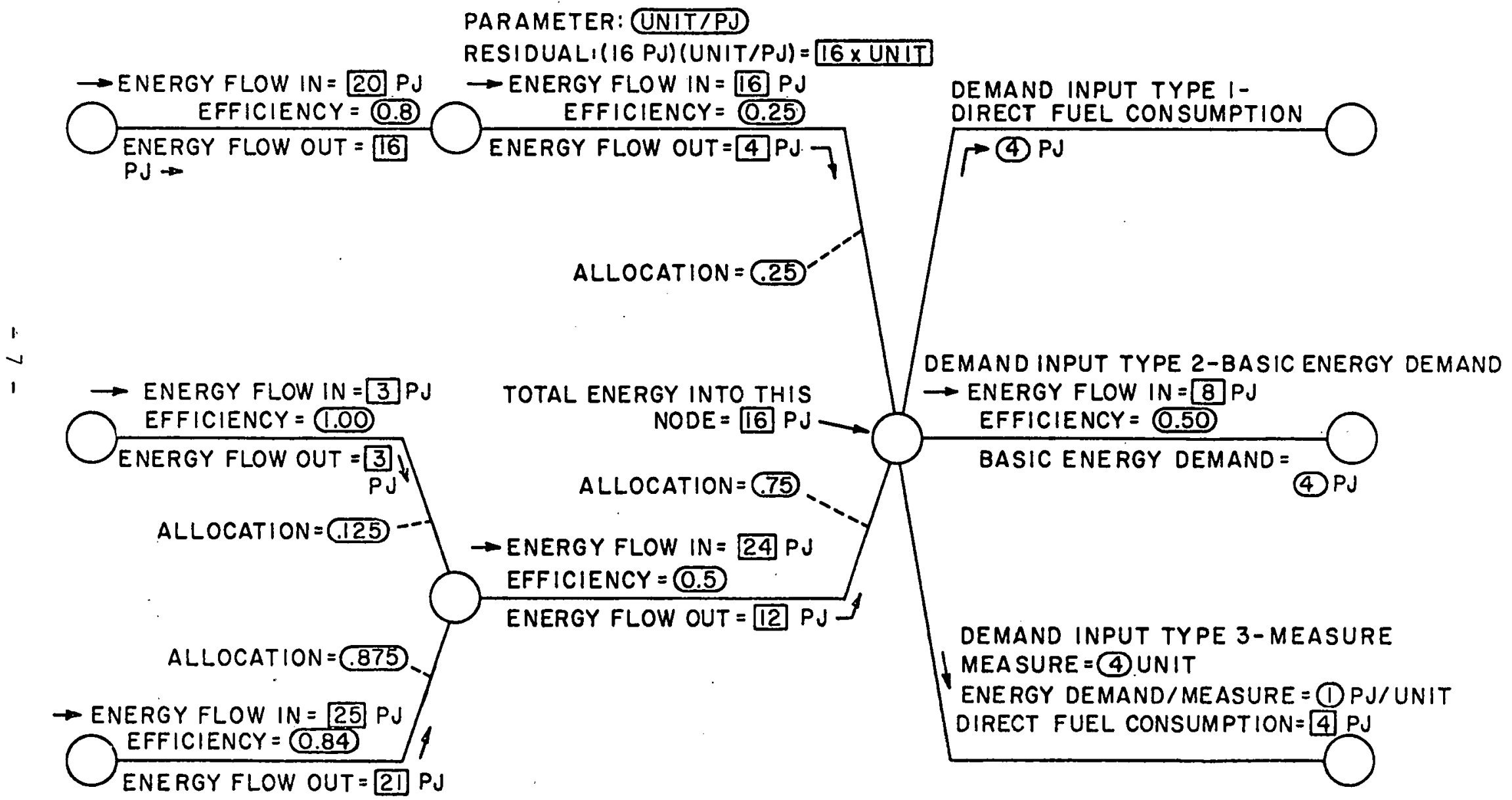

CIRCLED VALUES REPRESENT USER'S INPUT TO MODEL

VALUES CIRCUMSCRIBED WITH SQUARES ARE CALCULATED BY THE MODEL 
Figure 4

Energy Balance for Process

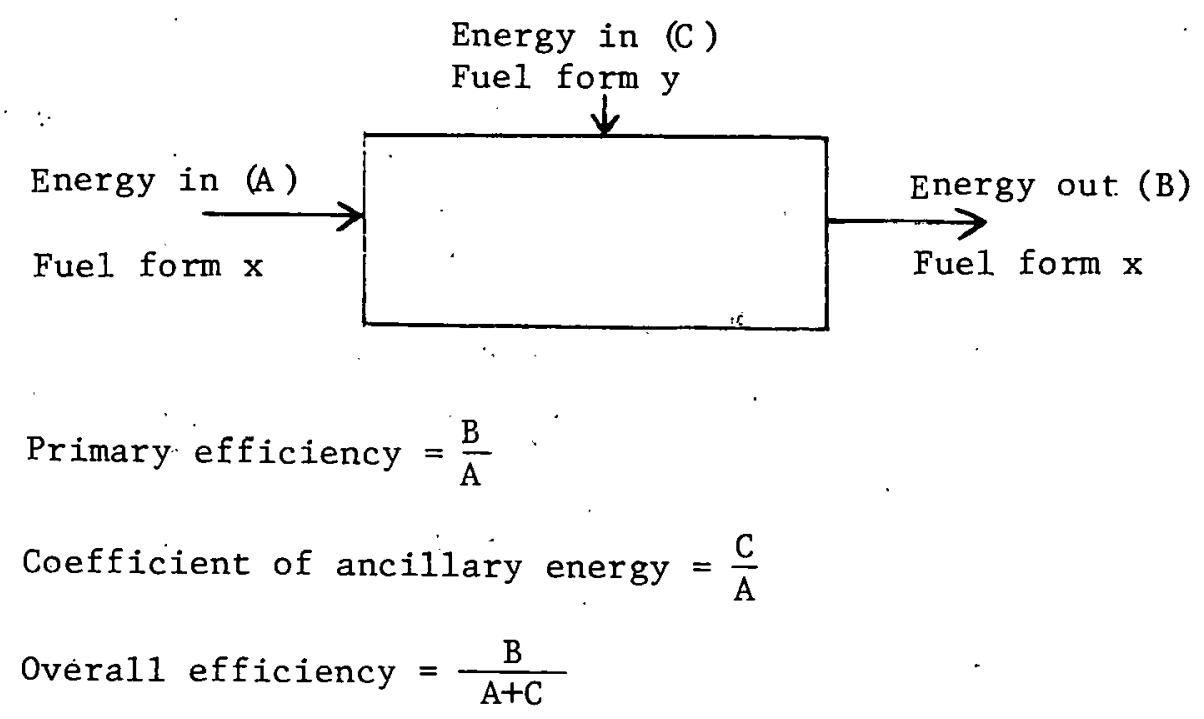

The concept of Relative Effectiveness is used to describe the efficiercy of end use devices. Relative effectiveness is distinguished from primary efficiency in that, in addition to reflecting the technical efficiency of the end use device (process), differences in utilization practices among fuels serving the same function are also incorporated.

For example, all electric houses tend to be more heavily insulated then houses that heat with oil. The relative effectivenss of electric and oil-heated houses reflects this difference.

The product of fuel delivered to the end use device (or process) and the relative effectiveness is the basic energy demand (see Section IB(alculations).

Energy per measure is used to convert demand expressed in units of use to direct fuel consumption, or conversely to translate fuel consumed by an end use function into units of use.

The demand-efficiency type selected for input to LDC-ESNS depends on both the available data and the demand projection methodology (which operates external to the model). 


\section{Market Allocations}

An RES diagram displays the choices that are available to a country to supply a particular fuel form to a specified use. When more than one option exists to supply a process with the energy it needs, the relative magnitude of each of the supply possibilities is known as the market allocation or market share of that technology. This number is expressed as the fraction of the total market for the product (see Section IB-Calculations).

5. Other Parameters

Using only the RES structure, demands, efficiencies, and allocations, LDC-ESNS can calculate energy flows through the system. However, additional optional inputs can greatly enhance the usefulness of the model.

Table III gives a list of optional parameters which can be included in LDC-ESNS. These include process efficiency components, residuals discharged to air and water, land use, occupational health, and fixed and operating costs. These data are inserted into the model in the form of units $/ 10^{15}$ joules input to the process. When the energy flow through a process is calculated, the model will then calculate the total quantity of the parameter generated by the process (see Section IB-Calculations).

B. Ca1culations

Flows in the energy system of a country represented by the RES diagram are calculated from demand to supply (right to left). In Figure 3, sample calculations of the type performed in LDC-ESNS are shown. Circled value represent those input to the model, while values circumscribed with a square are calculated during a model run.

Very simply, on the supply side of the RES the energy supplied to any node is split according to the market share of each of the processes which deliver energy to that node, yielding the energy out of each process. The energy out is divided by the primary efficiency to give the energy into the. process. This sequence is repeated until all energy flows in the supply side of the RES have been calculated.

On the demand side, three different calculations are made, depending upon which demand input type is entered into LDC-ESNS. If Direct Fuel Consumption (DFC) is provided (Type 1), no calculation needs to be made. Optionally, if either Basic Energy Demand of measure is desired, and the proper efficiency is supplied, these can be calculated from DFC. 
Parameter

Primary Fuel, Processing Loss

Primary Fuel, Physical Loss

Primary Fuel, Steam Raising

Ancillary Fuel, Coal

Ancillary Fuel, $0 i 1$

Ancillary Fue1, Gas

Ancillary Fuel, Electricity

Acids

Bases

Phosphates

Nitrates

Dissolved Solids, Misc.

Suspended Solids

Non-Degradable Organics

BOD

$\mathrm{COV}$

Thermal Rejection

Particulates, Air

Oxides of Nitrogen

Sulfur Dioxide

Hyd rocarbons

Carbon Monoxide

Carbon Dioxide

Aldehydes.

Solid Waste

Land Use

Occupational Deaths

Occupational Injuries

Occupational Man-Days Lost

Potential Disaster

Annual Costs, Fixed

Annual Costs, Operating

Totals Costs

Population Exposure, Radiation
Units

joule/ $10^{15}$ joule (in)

II

11

11

II

(1)

II

tonnes $/ 10^{15}$ jouie (in)

11

11

11

11

11

11

it

11

joule $/ 10^{15}$ joule (in)

tonnes $/ 10^{15}$ joule (in)

11

11

11

11

11

11

11

Square meter-yr/10 $0^{15}$ joule (in) Men $/ 10^{15}$ joule (in)

11

11

number $/ 10^{15}$ joule (in)

dollars $/ 10^{15}$ joule (in)

II

II

man-rem $/ 10^{15}$ joule (in) 


\section{Parameter}

High-Level Radioactive Waste

Tritium Emission

Krypton Emission

Energy Demand per Measure

Direct Fuel Consumption

Basic Energy Demand

Aqueous Ammonia

Trace Elements

Hydrochloric Acid

Hydrogen Cyanide

Anti-biofouling agent

Hydrogen Sulfide

Carbony1 Sulfide

Ammonia

Photochemical Oxidants

Boron

Make-Up Water

Plant Volume

Radon-222

Thorium-230 (Air)

Transuranics

Radium-226 (Air)

Uranium (Air)

Iodine-131

Misc. Fission Products (Air)

Noble Gases

Radium-226 (Liquid)

Uranium + Daughters (Liquid)

Ruthenium-106

Thorium-234

Misc. Fission Products (Liquid)

Solid Low Level Waste

- id High Level Waste

usid Low Level Waste

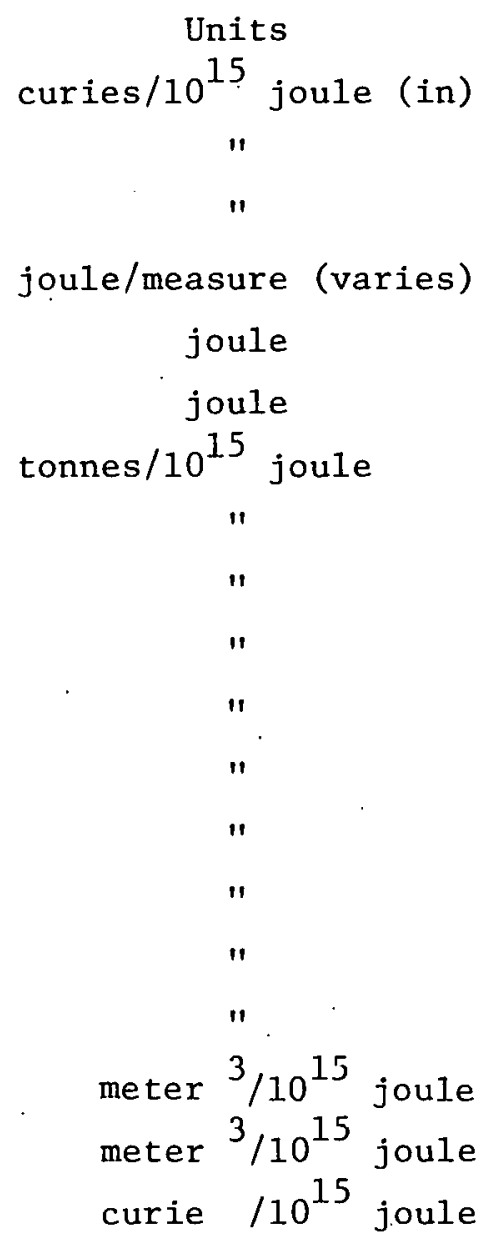

il

11

II

11

il

11

11

II

11

II

11

11

meter ${ }^{3} / 10^{15}$ joule

curie $/ 10^{15}$ joule

II 
When Basic Energy Demand (Type 2) is entered, it is divided by the relative effectiveness to give Direct Fuel Consumption. Measure (Type 3) multiplied b energy demand per measure yields DFC.

As can be seen from the calculations, LDC-ESNS is primarily an accounting mode1. Given certain data inputs and demand assumptions, a snapshot of the energy system at one point in time is produced, with energy flows and associated parameters summed and the required resources and imports tabulated.

C. Outputs

The output of LDC-ESNS is available in two basic formats; an inverted listing and a production run listing.

The inverted listing format, a segment of which is shown in Figure 5, highlights an additional use of LDC-ESNS, that of a very simple data base. An inverted listing displays, in an easily readable style, all data associater with each process and conversely, all processes which contain a certain data type. This capability allows data to be organized in a useable fashion as they are gathered, as well as permitting rapid checks of specific items of data with corresponding numbers from other sources.

A sample of a base-case production run for India is given in Figure 6 . For each process included in the run, the model displays the energy flow in and out of the process, the efficiency and market allocation assumed, and the total amounts of any environmental residual or other parameter for which a coefficient was previously entered.

A summary section follows the individual process listings. Displayed here are the total residuals generated by the system, the resources and imports of fuels required to satisfy the energy demand, and the breakdown of energy required by fuel and by sector. Commercial, noncommercial, and animate energy are summed separately.

\section{Composite RES Diagram}

An RES diagram which includes all present and potential processes from all LDCs, the Composite RES, is available as a master base file. This master file can be used for any LDC by setting the market allocation of technologles (processes) which are not present in that country's energy system to zero. The level of demand and technical coefficients used are country specific. This common format will allow summation of energy flows and other parameters over many LDCs. The composite RES is shown in Figure 7. Table IV lists processes specified in the current version of LDC-ESNS. 


\section{PERTURBATIONS}

Given the inputs discussed above, LDC-ESNS will reproduce a base-case RES for a specific country and year. However, the greatest utility of the model lies in the ability to modify any or all of the inputs and observe the changes resulting from these new inputs.

Modifications to a base case model run can be made by

a) substitution of a new value of any input variable for the original base case number,

b) addition of a value for a parameter in a particular process for which no previous value was indicated,

c) addition of new processes anywhere on the supply or demand side which were not present in the LDC composite RES diagram.

When any or all of these changes are made to a base or reference case, a perturbation case is calculated in which the effect of the modifications on the resources and imports are summed and the new flows through each process, as well as the residuals generated by these flows, are calculated. In addition, a comparison of any two cases, perturbation or base, can be printed if desired.

Three types of perturbation runs are especially useful to make with LDC-ESNS .

A trajectory is a single pathway which can be traced through the entire system. If all other demands and market. allocations are set to zero, then only the residual effects and magnitude of flows of the trajectory of interest are calculated and displayed. This technique can be used for example, to examine alternate supply possibilities for a given demand.

Somewhere between a full system run and a single trajectory lies consideration of a subsystem of the full energy system. A subsystem can display the portion of an energy supply system which serves only one type of demand, e.g., all electric demand or a subset of energy demand. This can in turn be manipulated and then added to the rest of the supply system.

Finally, the impact of introducing a new technology or set of technologies on the existing or future reference energy system can be evaluated and compared to other possible energy supply strategies. 


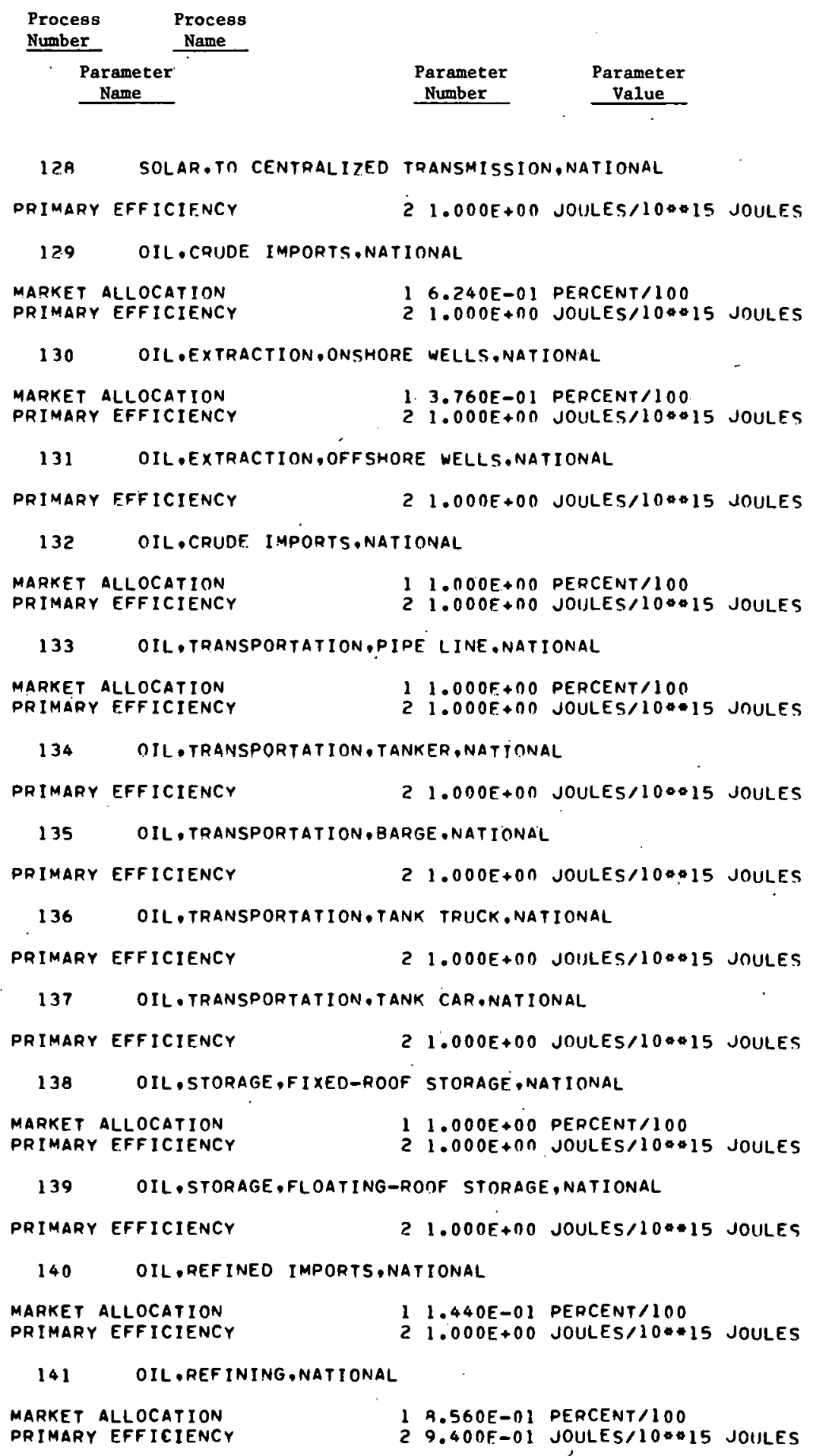

* All parameters selected from the list in Table III for which a value has been entered wll be listed for each process. 
FIGURE 6

PRODUCTION RUN LISTING - INDIA 
TOTAL EFFECTS AY PROCESS FOR THE YFAR 1972

ELECTRICITY, TRANSMISSION, NATIONAL

11

ENERGY FLOW IN=

FNERGY FLOW OUT= $\begin{array}{ll}\text { MARKET ALLOCATION } & 1.000000 E+00 \\ \text { PROCESS EFFICIENCY } & 8.300000 E-01\end{array}$

$\begin{array}{ll}\text { MARKET ALLOCATION } & 1.000000 E+00 \\ \text { PROCESS EFFICIENCY } & 8.300000 E-01\end{array}$

NUCLEAR,MINING.MINING UUNDERGROUNI URANIIJM MINF. .NATIONIL

ENERGY FLOW IN=
ENERGY FLOW OUT $=$

$1.3444 E+16 J 0 I L E$ 1. $3444 E+16 J 0 U L F$

MARKET ALLOCATION

PROCESS EFFICIFNCY

$1.0 \cap \cap \cap 00 E+00$ 1. DOONOOE + DO

NUCLEAR,MILLING,MILLING CONCENTRATION, NAFIONAL

16

ENERGY FLOW IN=

ENERGY FLOW OIIT=

$1.00 \cap \cap 00 E+00$ 1. ONOOOOE + DO

MARKET ALLOCATION

PROCESS EFFICIENCY NUCLEAR,PROCESSING, SOLVENT EXTRACTION,NATIONAL

\section{8}

ENERGY FLOW IN=

ENERGY FLOW OIIT=

MARKET ALLOCATION

PROCESS EFFICIENCY 1.000000 + 00

$2.2407 E+17$ JOULF

1. BS9BE+17 JOIJLE

1972

1972

1. $3444 E+14 J 01 J L E$ 1. $3444 E+1$ S JOIJLF

1972

1. $3444 E+16$ JOIILE 1. $3444 E+16 J 0 U L E$

1973

21

ENERGY FLOW IN=
ENERGY FLOW OIIT

1. $3444 E+16$ JOIILE 1. $3444 E+16$ JOILF

MARKET ALLOCATION

PROCESS EFFICIENCY . 1. ONO0OOE + 00
23

ENERGY FLOW TN=

FNERGY FLOW OIIT=

1. $0 \cap 0 \cap 00 E+00$

1. OOOOOOE +OD

MARKET ALLOCATION

PROCESS EFFICIENCY

NUCLEAR, OOWER PLANT, PWR POWER PLANT, NATIONAL
ENERGY FLOW IN=

ENERGY FLOW OUT =

1. $R O O N O O E-O 2$

3. DOBOBOE-0I

MARKET ALLOCATION

PROCESS EFFICIFNCY COAL, MINE.LIGNITF UNDERGROUND MINE, NATIONAL
44

ENERGY FLOW IN=

ENERGY FLOW OUT=

A. $00 \cap 0 \cap 0 E-01$ 1. OONOOOE +00
MARKET ALLOCATION

PROCESS EFFICIENCY

COAL. MINE. LIGNITE STRIP MINE. NATIONAL

45 FNERSY FLOW IN=

$3.0144 E+17$ JOILE

$1.3444 \mathrm{~F}+16 \mathrm{JOIILE}$
$1.3444 E+16$ JOULE 1. $3444 E+16$ JO1JLE

1972

$197 ?$ $4.0332 E+15$ JOILE

1972

1. $2057 E+1$ A JOIILE 1.2057E+18JOILE

$197 ?$ 


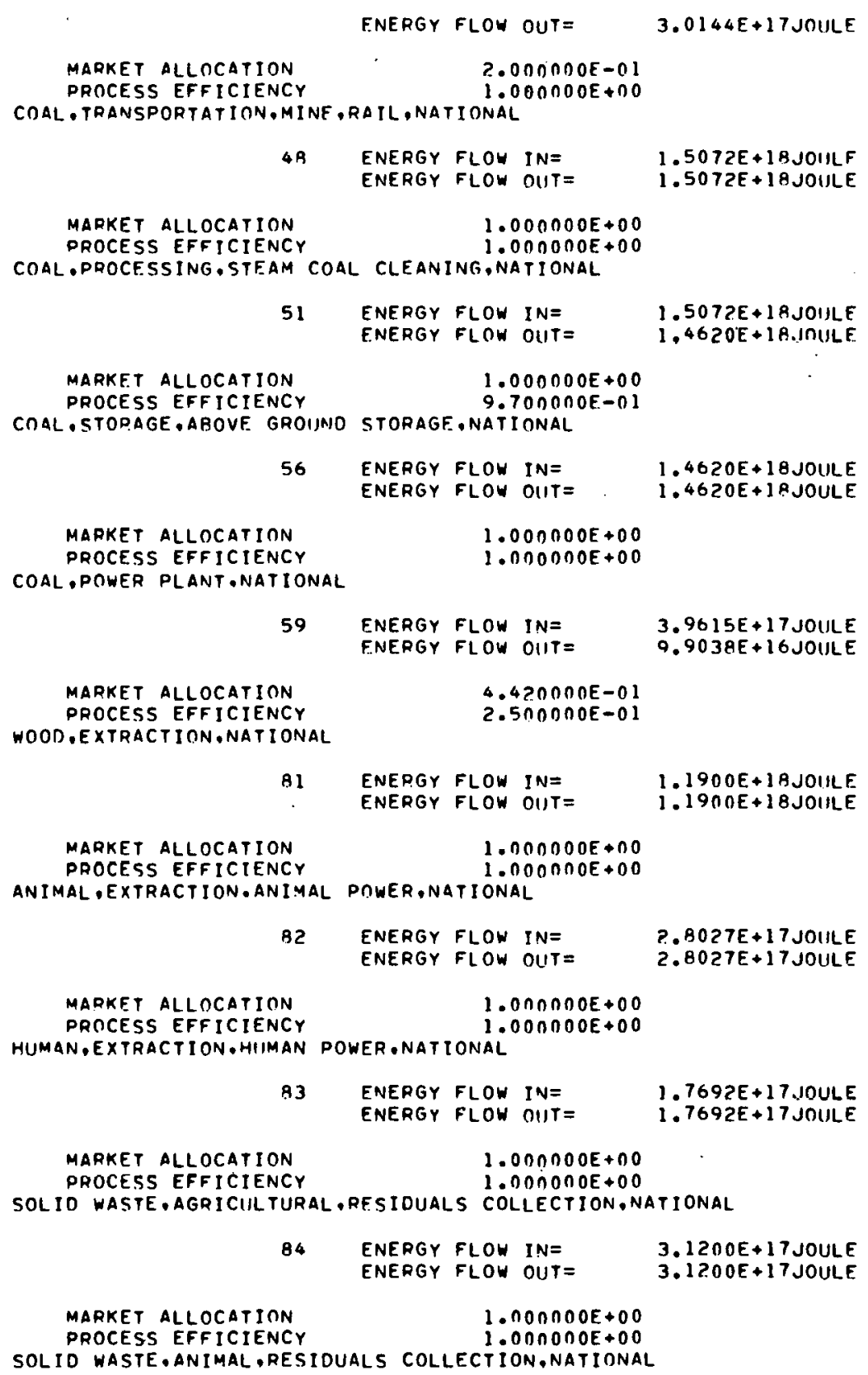

4 A

ENERGY FLOH IN=
ENERGY FLOW OUT=

$1.000000 E+00$

MARKET ALLOCATION

PROCESS EFFICIENCY COAL.PROCESSING.STEAM COAL CLEANING,NATIONAL

51

MARKET ALLOCATION PROCESS EFFICIENCY COAL.STODAGE.ABOVE. GROIJNO STORAGE. NATIONAL

$$
56
$$

ENERGY FLOW IN=

ENERGY FLOW OIIT=

MARKET ALLOCATION

PROCESS EFFICIENCY COAL .POWER PLANT, NATIONAL

59

ENERGY FLOW IN=
ENERGY FLOW OIIT=

$4.420000 E-01$

MARKET ALLOCATION

PROCESS EFFICIENCY WOOD,EXTRACTION,NATIONAL

\section{1}

ENEPGY FLOW IN=
ENERGY FLOW OUT= $2.5 \cap O D N O E-01$

$1.4620 E+18$ JOULE $1.4620 E+1$ P JOULE

$1.5072 E+18$ JOIJLE $1,4620 E+1$ B.JNULE

$1.5072 E+1 B$ JOIILF $1.5072 E+1$ B JOULE

$1.1900 E+1$ BJOILE 1.1900E+18JOILE

82

ENERGY FLOW IN= ENERGY FLOW OUT $=$

1. ONOกDOE +00 $1.000000 E+00$

MARKET ALLOCATION PROCESS EFF ICIENCY HUMAN,EXTRACTION.HIIMAN POWER.NATIONAL

83

$$
\begin{aligned}
& \text { ENERGY FLOW IN= } \\
& \text { ENERGY FLOW OUT= }
\end{aligned}
$$$$
1.000000 E+00
$$$$
\text { 1. DONONOE +OO }
$$

MARKET ALLOCATION MARKET ALLOCATION
PROCESS EFFICIENCY SOLIO WASTE, AGRICILTURAL, RESIDUALS COLLECTION, NATIONAL

.




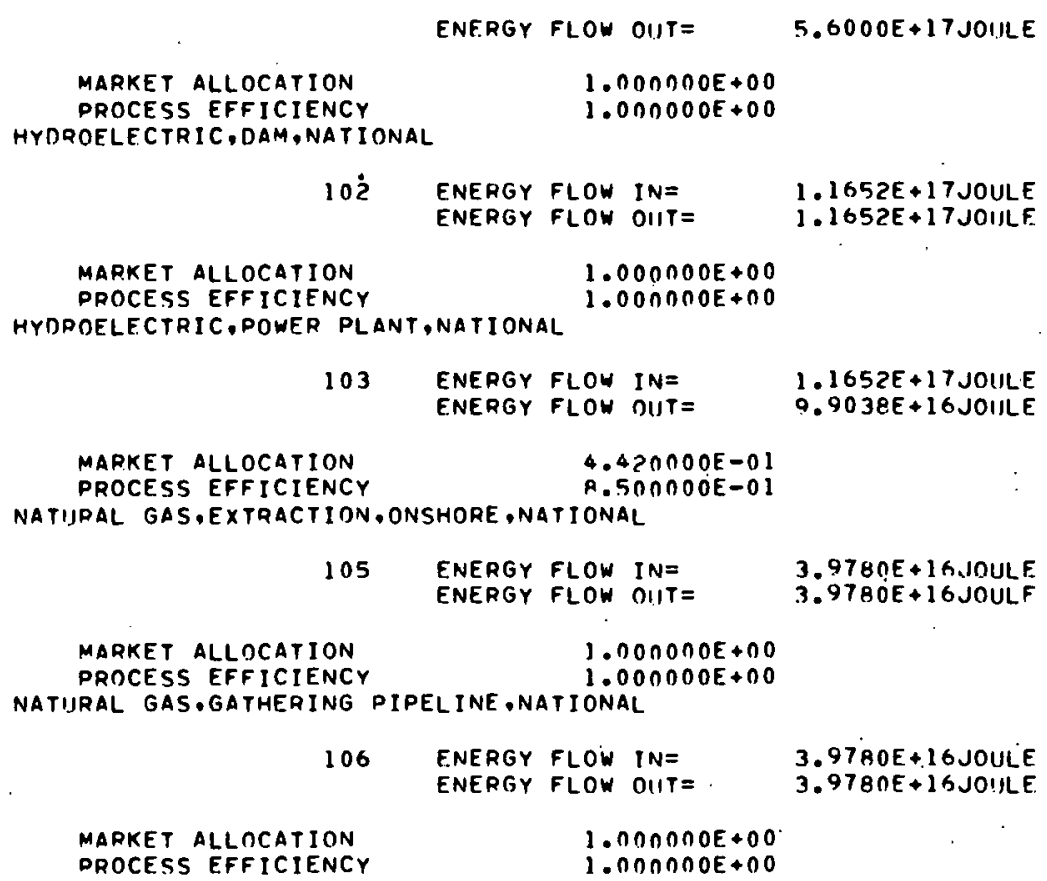

103

ENERGY FLOW IN=

ENERGY FLOW DUT $=$

$4.420000 E-01$

MARKET ALLOCATION

PROCESS EFFICIENCY

NATIJPAL GAS,EXTRACTION, ONSHORE, NATIONAL

105

106

3.9780E+16 JOULE $3.978 \cap E+16 J O ! U L$

$3.9780 E+16 . J D U L E$ 3.97BOE+16JOULF

109

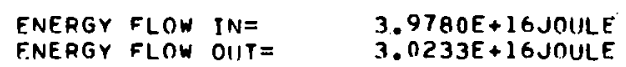

111

ENERGY FLOW IN $=$

$3.0233 E+16 J 0 U L$

MARKET ALLOCATION

PROCESS EFFICIENCY NATIJRAL GAS.STMRAGE. HDLDEP

\section{4}

ENERGY FLOW IN=

$1.000000 E+00$ $1.0 O N \cap O O E+00$
1972

1972

$197 ?$

$197 ?$

$197 ?$

1972

1972

$\begin{array}{ll}\text { MARKET ALLOCATION } & 1.000 N O O E+00 \\ \text { PROCESS EFFICIENCY } & 1.000 \cap 0 O+00\end{array}$ NATURAL GAS,STEAM-ELECTRIC POWER PLANT,NATIONAL
120

ENERGY FLON IN= $2.4647 E+15$ JOIILE

MARKET ALLOCATION PROCESS EFFICIENCY OIL.CRUDF IMPORTS.NATIONAL
$9.4798 E+15$ JOILE

$3.0233 E+16$ JOILE $3.0233 \mathrm{E}+16 \mathrm{JOIILE}$ 
ENERGY FLOW OUT=

$5.4112 E+17$ JOILE

$\begin{array}{lr}\text { MARKET ALLOCATION } & 6.240 \text { OONE-OI } \\ \text { PROCESS EFFICIENCY } & 1.00 O N O O E+00\end{array}$
$1.0 O O \cap B O E+00$

OIL,EXTRACTION,ONSHORE WELLS,NATIONAL

1.30

ENERGY FLOW IN=

$3.2606 E+17$ JOILE

ENERGY FLOW OUT $=\quad 3.2606 E+17$ JOULE

MARKET ALLOCATION

PROCESS EFFICIENCY

OIL, TRANSPORTATION,PIPE LINE, NATIONAL

3.7BNONOE-01

OIL.TRANSPORTATION.PIPE
133 $.000000 E+00$

ENERGY FLOW IN=

R.6718E+17JOULE

ENERGY FLOW DIIT $=\quad 8.671 \mathrm{gE}+17.1 \mathrm{NILE}$

MARKET ALLOCATION

PROCESS EFFICIENCY

OIL.STORAGE, FI XED-ROOF

$1.0 \cap D D O O E+00$

STORAGE , NAT IONAL

1972

138

ENERGY FLOW IN=

ENERGY FLOW OUT=
B.671AE+17 JOULE 8.671AE +17JOULE

OIL.REF INED IMPORTS, NATIONAL

$1.00 \cap \cap \cap O E+00$
$1.000 O O D E+00$

MARKET ALLOCATION

\begin{tabular}{|c|c|c|c|}
\hline 140 & $\begin{array}{l}\text { ENERGY } \\
\text { ENERGY }\end{array}$ & $\begin{array}{l}\text { FLOW IN= } \\
\text { FLOW OIIT }=\end{array}$ & $\begin{array}{l}1.3713 E+17 \text { JOULE } \\
1.3713 E+17 \text { JOULE }\end{array}$ \\
\hline $\begin{array}{l}\text { MARKET ALLOCATION } \\
\text { PROCESS EFFICIENCY } \\
\text { IL.REFINING .NATIONAL }\end{array}$ & \multicolumn{3}{|c|}{$\begin{array}{l}1.440000 E-01 \\
1.000000 E+00\end{array}$} \\
\hline 141 & $\begin{array}{l}\text { ENERGY } \\
\text { ENERGY }\end{array}$ & $\begin{array}{l}\text { FLOW IN= } \\
\text { FLOW OIIT= }\end{array}$ & $\begin{array}{l}\text { R.6718E+17 JOULE } \\
\text { R.1515E+17JOILE }\end{array}$ \\
\hline $\begin{array}{l}\text { MARKET ALLOCATION } \\
\text { PROCESS EFFICIENCY } \\
\text { STORAGE F IXED ROOF }\end{array}$ & \multicolumn{2}{|r|}{$\begin{array}{l}\text { A. } 560000 E-01 \\
9.40 \cap 000 E-01 \\
\text { VATIONAL }\end{array}$} & \\
\hline 143 & $\begin{array}{l}\text { ENERGY } \\
\text { ENERGY }\end{array}$ & $\begin{array}{l}\text { FLOW IN= } \\
\text { FLOW } 0 I I T=\end{array}$ & $\begin{array}{l}9.522 \mathrm{BE}+17 \text { JOULF } \\
9.5228 E+17 \text { JOULE }\end{array}$ \\
\hline $\begin{array}{l}\text { MAPKET ALLOCATION } \\
\text { PROCESS EFFICIENCY }\end{array}$ & & $\begin{array}{l}1.0 \cap O \cap \cap O E+00 \\
1.0 O \cap O \cap O E+00\end{array}$ & \\
\hline
\end{tabular}

OIL,OIL FIRED POWER PLANT,NATIONAL

1. DONOODE + OO

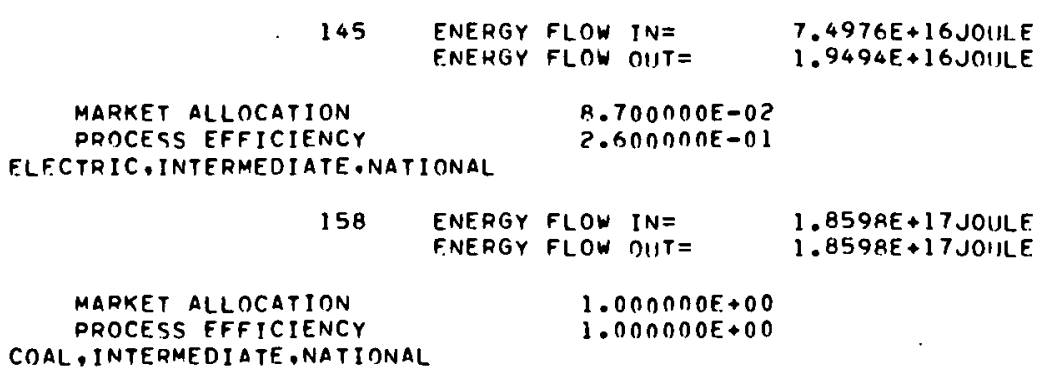

$197 ?$

197?

$197 ?$

$197 ?$

1972

1.0658E + I BJOULF 
ENERGY FLOW OUT $=$

\section{ODOOOOE + OO}

1. $D O \cap \cap O D E+0 O$

PROCESS EFFICIENCY WOOD. INTERMEDIATE. NATI ONAL

161

ENERGY FLOW IN= ENERGY FLOW OUT=

$1.000000 E+00$

$1.00 \cap 000 E+00$

MARKF T ALLOCATION

PROCESS EFFICIENCY ANIMAL DOWER. INTERMEDIATE, NATIONAL

\section{ENERGY FLOW IN=} ENERGY FLOW OUTT=

\subsection{E+17 JOULE 2.8027E+17JOHLE}

MARKET ALLOCATION PROCESS EFFICIENCY

1. $000000 E+00$

1. OONONOE +00

$1.0658 E+18$ JOIJE.

$1.1900 E+18$ JOULF
1972

1.190OE+18JOULE

1972

$197 ?$

$1.7692 E+17$ JOIJE $1.7692 E+1.7$ JOILE

ENERGY FLOW IN=
ENERGY FLOW OIT $=$

$1.000000 E+00$

$1.000000 E+00$

MARKET ALLOCATION

DRIED AGRICULTURF RESI DIJALS. INTERMEDIATE . NATI ONAL

1972

164 ENERGY FLOW IN $=\quad 3.1200 E+17$ JOULE

ENERGY FLOW OUT $=\quad 3.1200 E+17$ JOILE

MARKET ALLOCATION $1.000000 E+00$

PROCESS EFFICIENCY

DRIED ANIMAL RESIDUALS. INTERMEDIATE, NATIONAL

1972

\section{5}

ENERGY FLOW IN=

ENERGY FLOW OUT=

$5.60 \cap 0 E+17$ JOULE

$5.6000 E+17$ JOULF

1. OONOOOE + OO

1. OONONOE + OO

MARKET ALLOCATION

NATURAL GAS, INTERMEDIATE, NATIONAL
169

FNERGY FLOW IN=
ENERGY FLOW DUT=

$1.000000 E+00$

I. ODOOODE +0O
PROCESS EFFICIENCY OIL. INTERMEDIATE. NATIONAL

\section{3}

ENERGY FLOW IN=

ENERGY FLOW OUT $=$

1. OONOONE+OO

1. OOOOOOE + 00

MARKET ALLOCATION

RURAL HOUSEHOLD, WOOD. INTERMEDI ATE , NATIONAL
261

ENERGY FLOW IN=
ENERGY FLOW OIIT=
$1.000 \cap 00 E+00$

$1.0 \cap O \cap O O E+10$

MARKFT ALLOCATION

RURAL HOUSEHOLD, COAL, INTERMEDIATE, NATIONAL

$2.0753 E+16$ JNULE

$2.0753 E+16$ JOULF

1972

1972

B. $7730 E+17$ JOULE B. $7730 E+17$ JOULE

1972

$1.1900 E+18$ JOULE $1.1900 E+18 J O U L E$

1972

262 ENERGY FLOW IN $=$ R.440OE+16JOIJLE 
MARKET ALLOCATION PROCESS EFFICIFNCY

$1.000000 E+00$ $1.000000 E+D 0$

264 ENERGY FLOW IN=
ENERGY FLOW OOTT

MARKET ALLOCATION $1.000 \cap$ OOE +00

PROCESS EFFICIENCY $1.000000 E+D O$

RURAL HOUSEHOLD.OIL.INTERMEDIATE. NATIONAL

1977

$$
\begin{array}{lll}
265 & \text { ENERGY FLOW IN } & 1.6240 E+17 \text { JOIIE } \\
\text { ENERGY FLOW OUT }= & 1.6240 E+17 \text { JOULE }
\end{array}
$$

MARKET ALLOCATION $1.00 \cap 00 O E+00$

PDOCESS FFFICIENCY 1. OOOONDE + OO

PIJPAL HOUSEHOLD. ANIMAL WASTE, INTERMEOIATF, NATIONAL

1972

$$
\begin{array}{lll}
266 & \text { ENERGY FLOW IN } & 5.6000 E+17 \text { JOILLE } \\
\text { ENERGY FLOW OUT }= & 5.6000 E+17 \text { JOULE }
\end{array}
$$

MARKET ALLOCATION

PAOCESS E.FFICIENCY

1. $\cap 00000 E+00$

1. $0 \cap \cap \cap 00 E+00$

RIJAAL HOUSEHOLD,AGRICULTURAL PESIDUIALS. INTERMEOIATE, NATIONAL

$197 ?$.

$$
\begin{aligned}
& 269 \text { ENFRGY FLOW.IN= } \quad \\
& \text { ENERGY FLOW OIT }=
\end{aligned}
$$

MARKET ALLOCATION

PADCESS EFFICIENCY

$1.000 O N O E+00$ 1. $\cap \cap \cap \cap \cap O E+00$

PURAL HOUSEHOLD, WOOD, COOKING, NATIONAL

\subsection{1}

ENEPGY FLOW IN= $\quad 1.1900 E+19 J 0 I L E$ BASIC ENEPGY DEMAND $=1.1900 E+17$ JOILE

PROCESS EFFICIENCY
AIJPAL HOUSEHOLN, COAL COOKING NATIONAL

$$
1.0 O \cap \cap D O E-01
$$

272 ENERGY FLOW IN= $9.4400 E+16 \mathrm{JOIJLE}$ BASIC ENERGY DEMAND $=.8 .4400 E+15$ JOULE

PROCESS EFFICIENCY

$$
1.000000 E-01
$$

RURAL HOUSEHOLO.OIL . COOKING .NATIONAL

PROCESS EFFICIENCY

$$
\text { 5. OOกOกOE-01 }
$$

RUPAL HOUSEHOLD. ANIMAL WASTE, COOKING.NATIONAL

$$
\begin{array}{lll}
276 & \text { ENERGY FLOW IN }= & 5.6000 E+17 \text { JOULE } \\
\text { BASIC ENERGY NFMAND }= & 5.6000 E+16 \text { JOIJLE }
\end{array}
$$

PROCESS EFFICIENCY 1.000 DOOE-01

RURAL HOIJEHOLD.AGRICULTURAL RESIDUALS, COOKING NATIONAL

PROCESS EFFICIENCY 1.0ONONOE-01

DIIRAL HOIJEHOLD.ELECTRIC,LIGHTING .NATIONAL 
PROCESS EFFICIENCY

$1.00 \cap 000 E+00$

RURAL AGRICULTURE, NATURAL GAS, INTERMEDIATE. NATIONAL

315

ENERGY FLOW IN= $9.4700 E+15 J 0 U L F$ ENERGY FLOW OUT $=\quad 9.4700 E+15$ JOILE

MAPKET ALLOCATION

PROCESS EFFICIENCY

$1.00 \cap 000 E+00$

1. DONDOOE +OO

RURAL AGRICULTURF. ELECTRIC. INTERMEDIATE, NATIONAL

316

ENERGY FLOW IN=

$1.784 \mathrm{AE}+16$ JOIILE ENERGY FLOW DIIT=
MARKET ALLOCATION PROCESS EFFICIENCY

\section{1. $\cap 00000 E+0.0$ \\ $1.0 O \cap O O D E+00$}

RUPAL AGRICULTURE.OIL. INTERMEDIATE , NATIONAL

317

MARKFT ALLOCATION

PROCESS EFFICIENCY $\begin{array}{ll}\text { ENERGY FLOW IN= } & 1.2680 E+17 \text { JOIUE } \\ \text { ENERGY FLOW DIIT }= & 1.2680 E+17 \text { JOULE }\end{array}$

\section{OONOOOE + OO}

1. DONODOE + OO

RIIRAL AGRICULTURE. ANIMAL POWER, INTERMENIATE. NATIONAL

\section{ENERGY FLOW IN= ?.8027E+17JOULE} F.NERGY FLOW OIIT $=\quad 2.8027 E+17$ JOILE

MARKET ALLOCATION

PROCESS E.FFICIENCY

$1.000000 E+00$

1. InODOOE+ DO

RURAL AGRICULTURE. HUMAN POWER, INTERMEDIATE, NATIONAL

326 ENEAGY FLOW INE $1.7692 E+17$ JOULE ENEAGY FLOW OIIT $=\quad 1.7692 E+17$ JOIILE

MARKET ALLOCATION

PROCESS EFFICIENCY

$1.00 \cap 000 E+00$ 1. OONONOE +00

RIIRAL AGRICULTURE. NATURAL GAS FEFDSTOCKS.NATIONAL

ENEPGY FLOW IN $=\cdot \cdot \quad 8.4700 E+15 \mathrm{JOULF}$ BASIC ENFRGY DEMAND $=8.4700 E+15$ JOILE

PROCESS EFFICIENCY

1. OONODOE + DO

RIJAAL AGRICULTUAE. OIL FFEDSTOCKS, NATIONAL

334

ENERGY FLOW IN=

7. 3BOOE +16 JOIULF

BASIC FNERGY TEMAND $=7.3800 E+16$ JOULF.

PROCESS EFFICIENCY

1. OONOOOE + OO

RURAL,ELECTR.IC,AGRICULTURE END USF I.NATIONAL

338

FNERGY FLOW IN= $1.7846 E+16$ JOULF

BASIC FNERGY DEMAND $=1.1600 E+16 J O U L E$

PROCESS EFFICIENCY $6.500000 E-01$

DURAL, OIL, AGRICULTURE ENO USE 1.NATIONAL

339

5.30 OOE +16 JOIILF

RASIC FNERGY DEMAND $=1.0600 E+16$ JOIILE
$197 ?$

1972

1972 
PROCESS EFFICIENCY 2.000000E-01 RURAL ANIMAL POWER.AGRICULTURE END USE I.NATIONAL

PROCESS EFFICIENCY $1.500000 E-01$

RURAL. HUMAN POWER,AGRICULTURE END USE I,NATIONAL

$$
\begin{aligned}
& 346 \text { ENERGY FLOW IN= } \\
& \text { PASIC ENFRGY DEMANO }=\quad 7.9200 E+15 \text { JOULE } \\
& 7.3800 E+14 \text { JOULE }
\end{aligned}
$$

PROCESS EFFICIENCY $1.500000 E-01$

RURAL ANITALL POWER, AGRICULTIIRE END USE ?.NATIONAL

$$
\begin{aligned}
& 351 \text { ENERGY FLOW IN= } \\
& \text { BASIC FNERGY DEMAND }= \\
& 2.50005+17 \text { JOILE } \\
& 2.500 E+16 \text { JOULE }
\end{aligned}
$$

PROCESS EFFICIENCY 1.0ONOOOE-01 RURAL. HUMAN POWER.AGRICULTURE END USE Z.NATIONAL

PROCESS EFFICIENCY 1.00NODOE-01 INDUSTRY, ELECTRIC. INTERMEDIATE, NAYIONAL

$$
\begin{array}{lll}
510 & \text { ENERGY FLOW IN }= & 1.2283 E+16 \text { JOULE } \\
\text { ENERGY FLOW OIJT }= & 1.2283 \mathrm{~J}+16 \mathrm{JOIJE}
\end{array}
$$

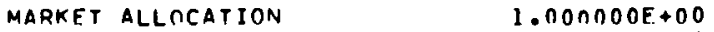

$$
\begin{array}{lll}
512 & \text { ENERGY FLOW IN= } & 2.1167 E+17 \text { JOIILF } \\
\text { ENERGY FLOW OIIT } & 2.1167 E+17 \text { JOILE }
\end{array}
$$

MARKET ALLOCATION $1.000000 E+00$

PROCESS EFFICIENCY $1.000000 E+00$

INDUSTRY ELECTRIC. INDUSTRY I.NATIONAL

$$
\begin{array}{ll}
513 \text { ENERGY FLOW IN } & 1.2800 E+17 \text { JOULE } \\
\text { AASIC ENERGY DEMAND }= & 1.2800 E+17 \text { JOULF. }
\end{array}
$$

PROCESS EFFICIENCY $1.00 \cap 000 E+00$

INDIISTRY NATURAL GAS. INDUSTRY I. NATIONAL 
PROCESS EFFICIENCY INDUSTRY.COAL - INDIISTRY I NATIONAL

PROCESS EFFICIENCY

$6.000000 E-01$

INOUSTRY, DIL. INDIJSTRY I,NATIONAL

\section{6}

FNERGY FLOW .IN= BASIC ENERGY DEMAND =

PROCESS EFFICIENCY INDUSTRY, COAL , IPON AND $6.000000 E-01$ STEEL.NATIONAL $1.2700 E+17$ JOULE

$197 ?$

$197 ?$ TRANSPORTATION. COAL, INTERMEDIATE, NATIONAL

3.470RE+17JOIJLF R. $3300 \mathrm{E}+16 \mathrm{JOIJLE}$

ENERGY FLOW IN=

556

ENERGY FLOW IN= ENERGY FLOW OUT=

$1.000 n \cap 0 E+00$

MARKET ALLOCATION PROCESS EFFICIENCY TRANSPORTATION, OIL, INTERMEDIATE, NATIONAL

557

ENERGY FLOW IN=
ENERGY FLOW OIIT=

$1.000000 E+00$

MARKET ALLOCATION

PROCESS EFFICIENCY 1. OONONOE+00 TRANSPORTATION ELFCTRIC. INTERMEDIATE . NATIONAL

$$
558
$$

ENERGY FLOW IN= ENERGY FLOW OUT=

$6.3300 E+15$ JOULE 6.3300 E + 15 JOULE 3.210OE+17JOULF
$3.2100 E+17$ JOHLF
MARKET ALLOCATION PROCESS EFFICIENCY I.0ONODOE +00
560

ENERGY FLOW INE BASIC ENERGY DFMAND =

$197 ?$

1972

$7.7333 E+16 J O I L E$ 1. 1600 E + 16 JOULE

PPOCESS EFFICIENCY

$1.500000 E-01$ TRANSPORTATION, OIL, SHIP, NATIONAL

561

ENERGY FLOW IN= BASIC ENFRGY DEMAND $=$
4.7500E +16 JOULE $9.5000 E+15$ JOULE.

PROCESS EFFICIENCY 2. $000000 E-01$

TRANSPORTATION, OIL, A IRPLANE, NATIDNAL

564 ENERGY FLOW IN= $4.2333 E+16$ JOULE BASIC ENEDGY DEMAND $=1.2700 E+16$ JOILE

PROCESS EFFICIENCY 3. $000000 E-01$ TRANSPORTATION. OIL , FREIGHT TRUCK, NATIONAL 


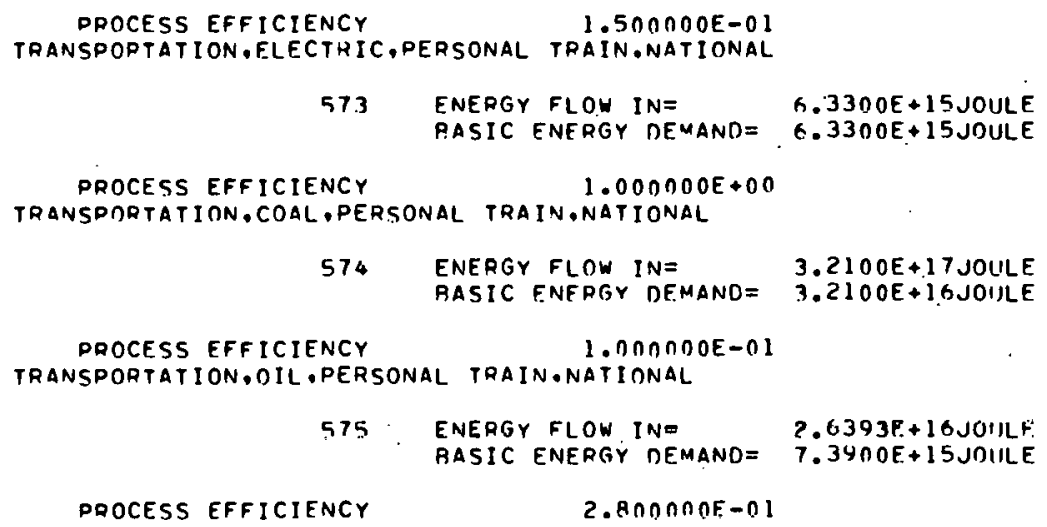




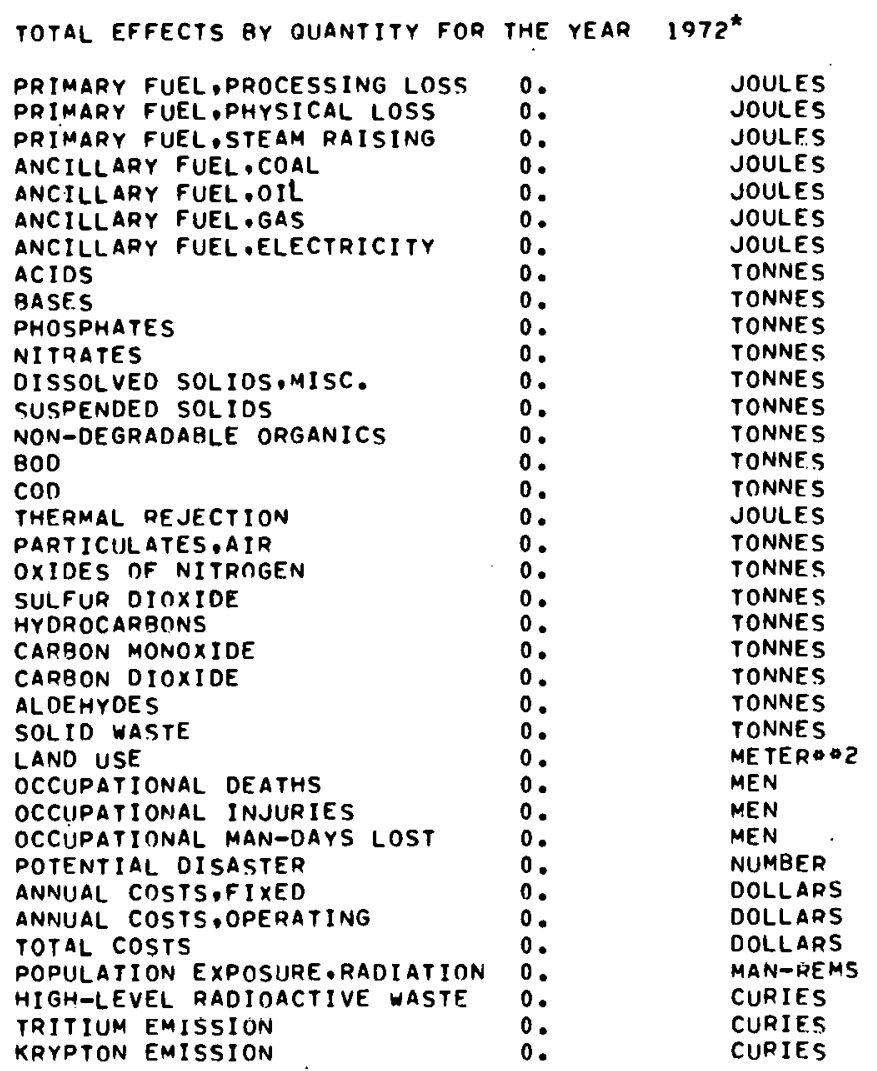

TOTAL RESOURCES CONSUMED IN JOULE FOR THE YEAR 1972 FOR THIS RASE CASE/TRAJECTORY RUN

$\begin{array}{ll}\text { PETROLEUM } & 1.0043 E+18 \\ \text { COAL } & 1.5072 E+18 \\ \text { HYDROELECTRIC } & 1.1652 E+17 \\ \text { NUCLEAR } & 1.3444 E+16 \\ \text { GAS } & 3.9780 E+16 \\ \text { WOOD } & 1.1900 E+19 \\ \text { WASTE } & 8.7200 E+17 \\ \text { ANIMAL } & 2.8027 E+17 \\ \text { HUMAN } & 1.7692 E+17\end{array}$

TOTAL RESOURCES CONSUMEO BY ENERGY TYPE

$\begin{array}{ll}\text { COMMERCIAL } & 2.6812 E+18 \\ \text { NON-COMMERCIAL } & 2.5192 E+18 \\ \text { ANIMATE } & 4.5719 E+17\end{array}$

GRAND TOTAL RESOURCE CONSUMPTION=5.2004E+18

*Environmental and Technological Parameters were not entered for this analysis. 
ENFPGY END USE INPITS RY SECTOR AND FUEL TYPE FOR 1972

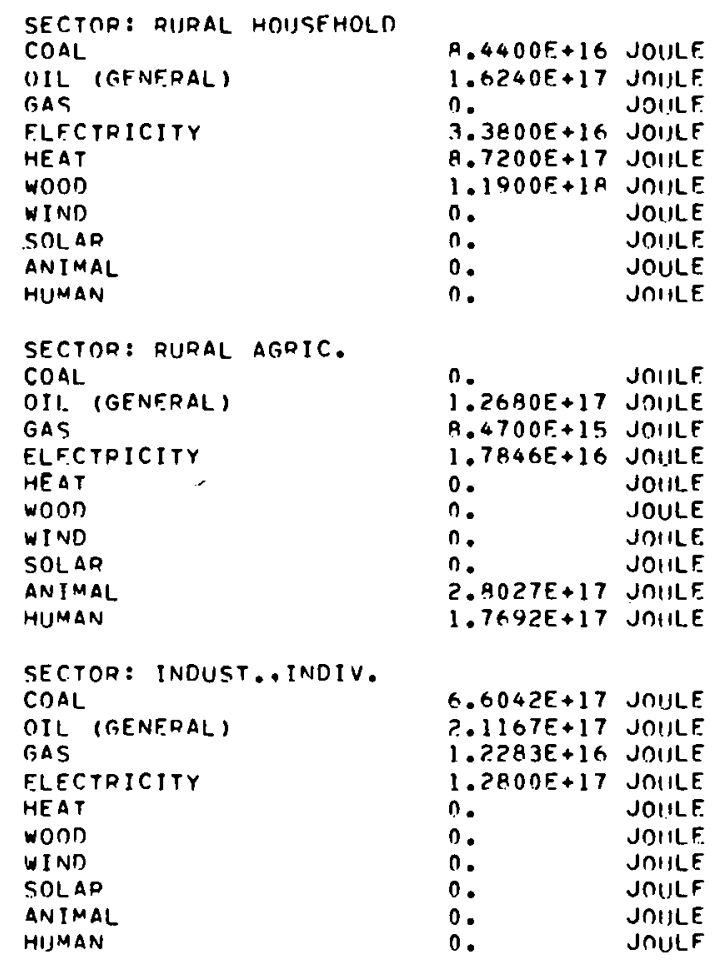

SECTOR: TRANS..PERSONAL

COAL

OIL (GENERAL)

GAS

FLECTRICITY

HEAT

WOAn

WIND

SOLAR

ANIMAL

HUMAN

$\begin{array}{ll}3.2100 E+17 & \text { JOIILE } \\ 1.9356 E+17 & \text { JOIILE } \\ 0 . & \text { JOIILE } \\ 6.3300 E+15 & \text { JOIILE } \\ 0 . & \text { JOILE } \\ 0 . & \text { JOULE } \\ 0 . & \text { JOULE } \\ 0 . & \text { JOILE } \\ 0 . & \text { JOIILE } \\ 0 . & \text { JOIILF } \\ & \\ 0 . & \text { JOILE } \\ 1.8297 E+17 & \text { JOULE } \\ 0 . & \text { JOIJLE } \\ 0 . & \text { JOIJLE. } \\ 0 . & \text { JNIILE } \\ 0 . & \text { JOILE } \\ 0 . & \text { JOULE } \\ 0 . & \text { JOIILE } \\ 0 . & \text { JOIJLE } \\ 0 . & \text { JNUILE }\end{array}$




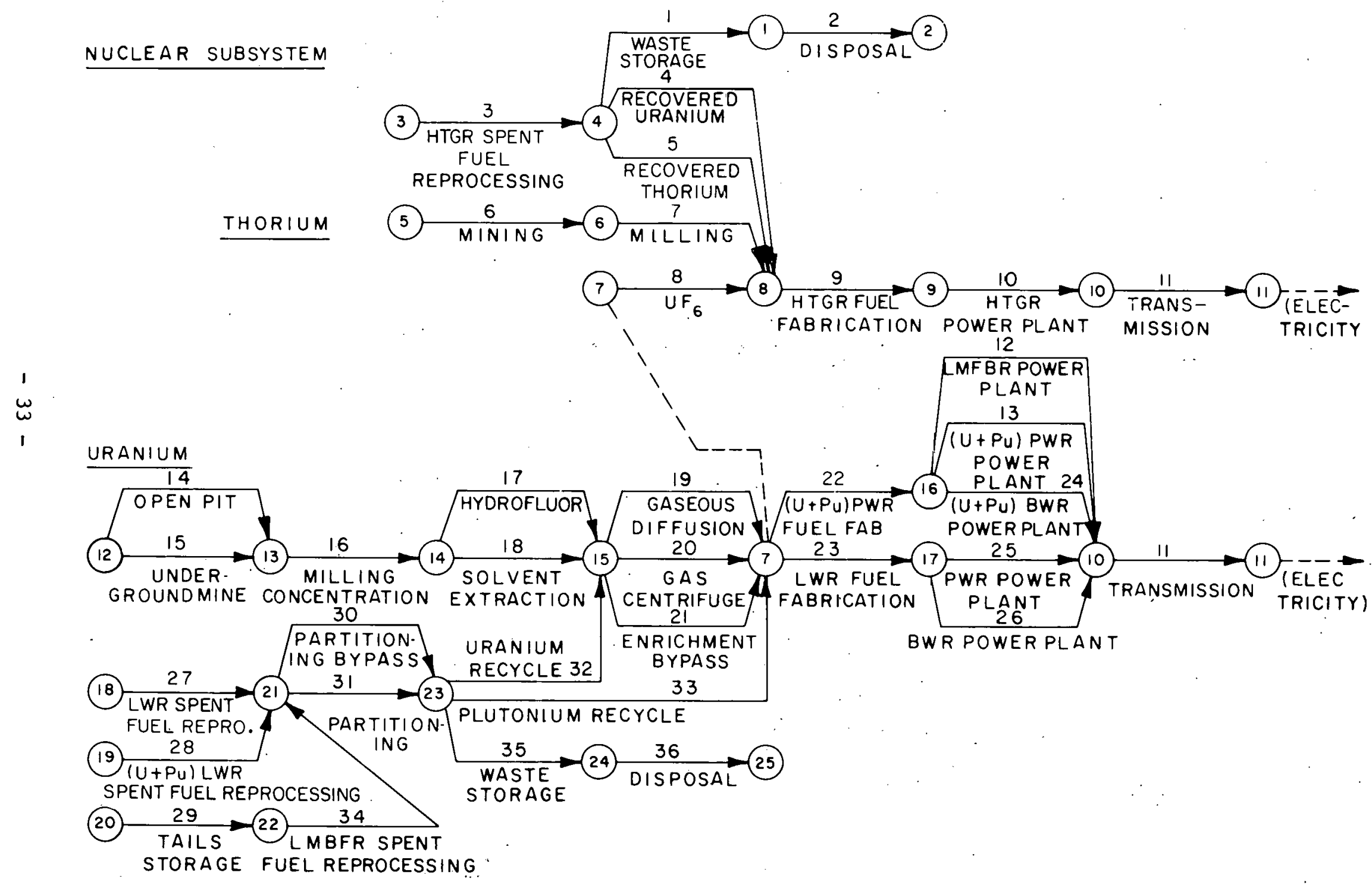




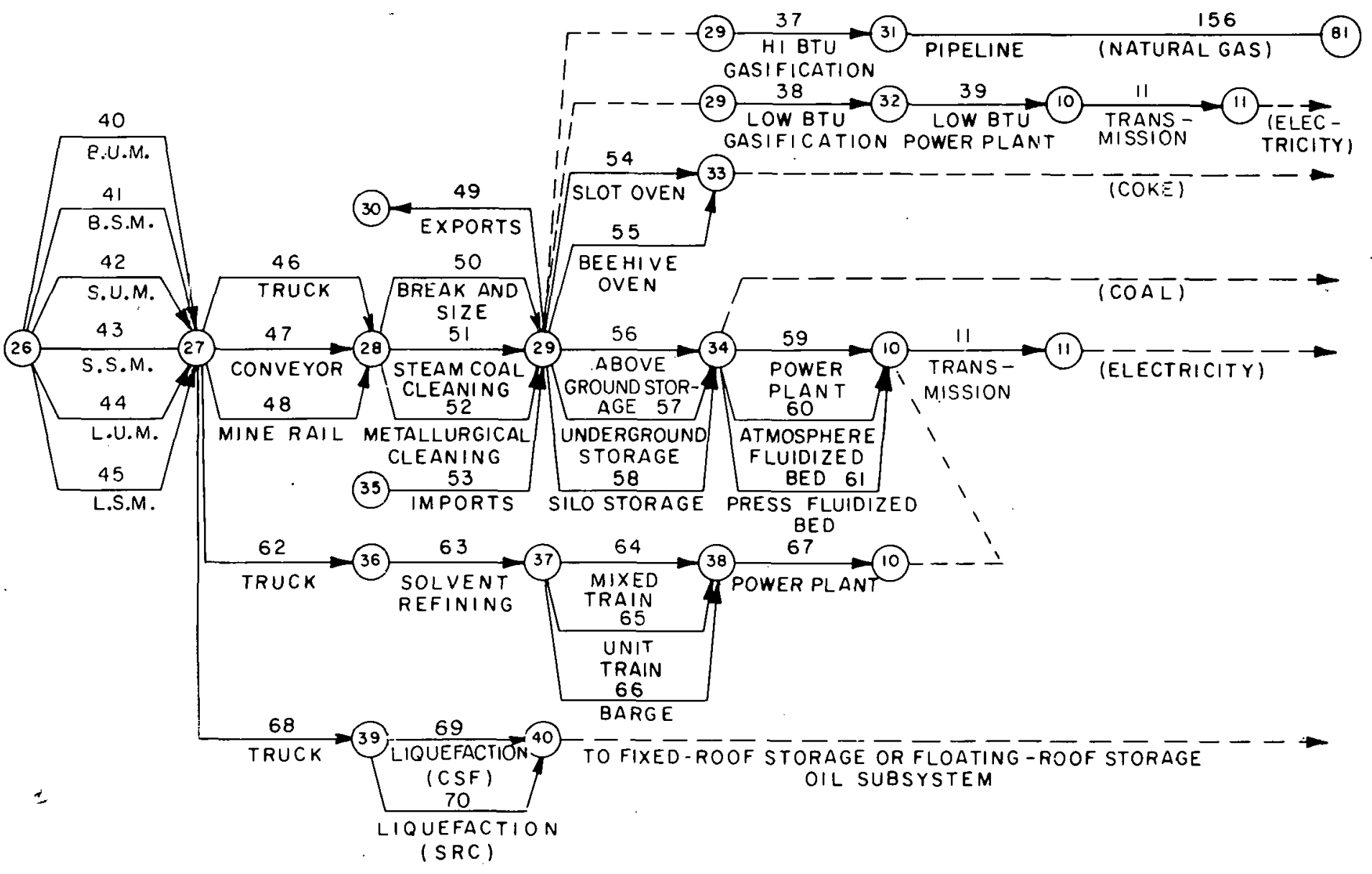

B.U.M. = BITUMINOUS UNDERGROUND MINE

B.S.M. = BITUMINOUS STRIP MINE

S.U.M. = SUBBITIJMINOUS UNDERGROUND MINE

S.S.M. = SUBBITUMINOUS STRIP MINE

L.U.M. = LIGNITE UNDERGROUND MINE

L.S.M. = LIGNITE STRIP MINE 
GEOTHERMAL SUBSYSTEM
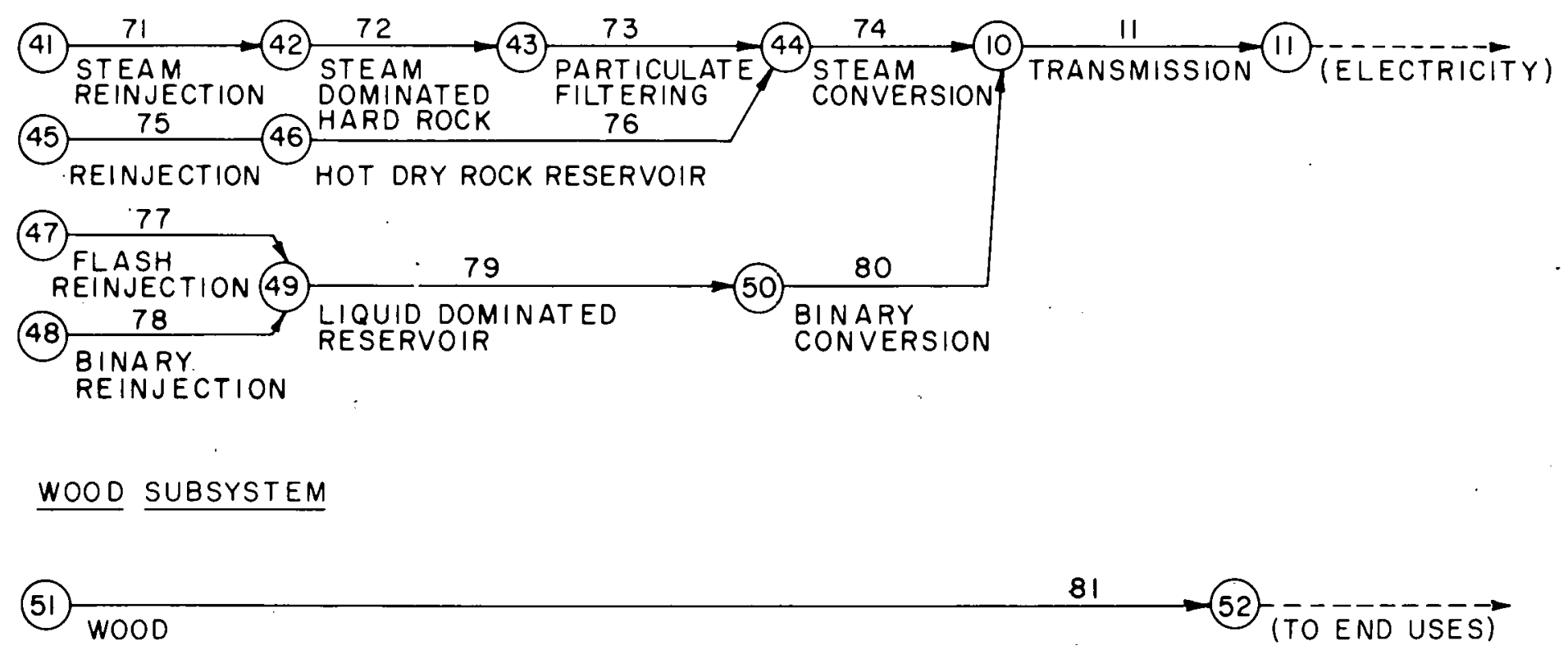

ANIMAL SUBSYSTEM

(53) ANIMAL POWER
HUMAN SUBSYSTEM
(55) HUMAN POWER


LOC-ESNS ENERGY SYSTEM SUPPLY PROCESS NETWORK (SOLID WASTE, WIND)

\section{SOLID WASTE SUBSYSTEM}

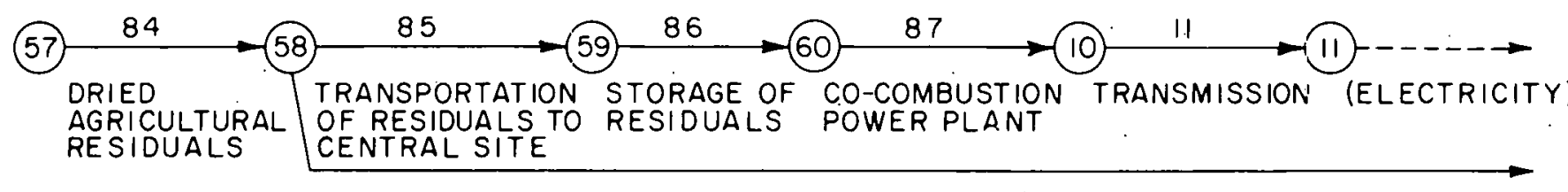

(TO DIRECT END USE)

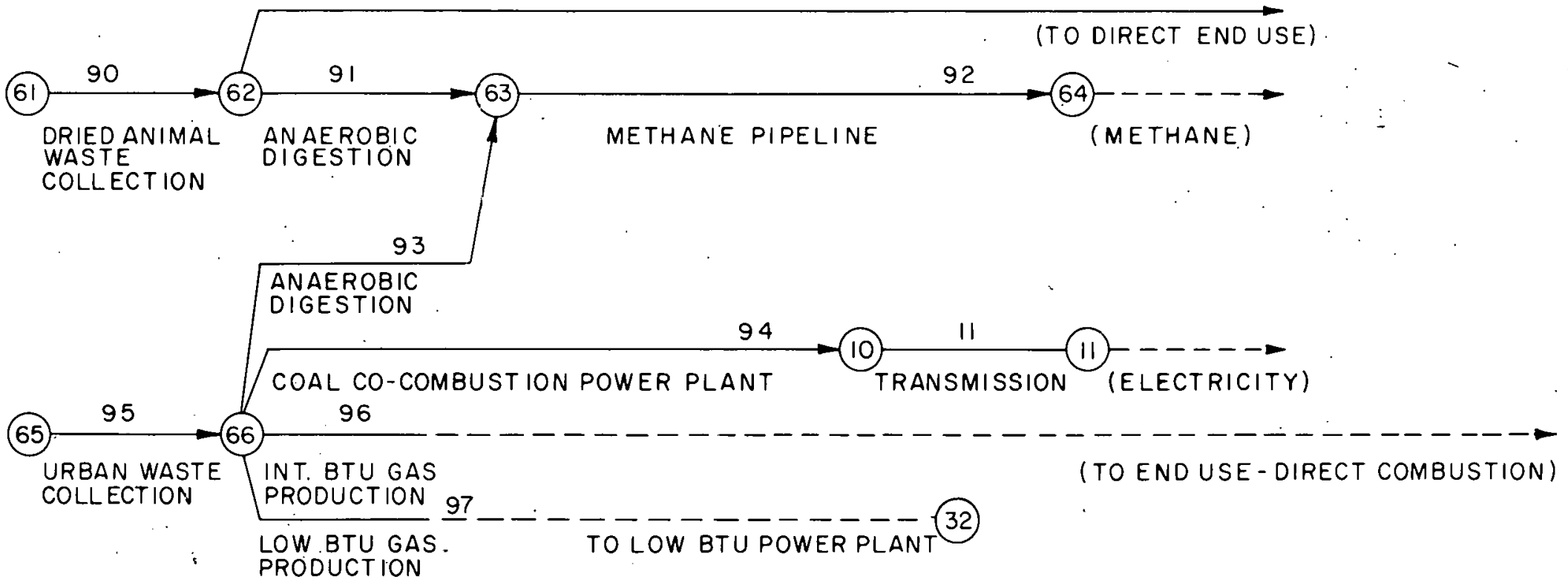

WIND SUBSYSTEM

WIND POWER


HYDROELECTR.IC SUBSYSTEM
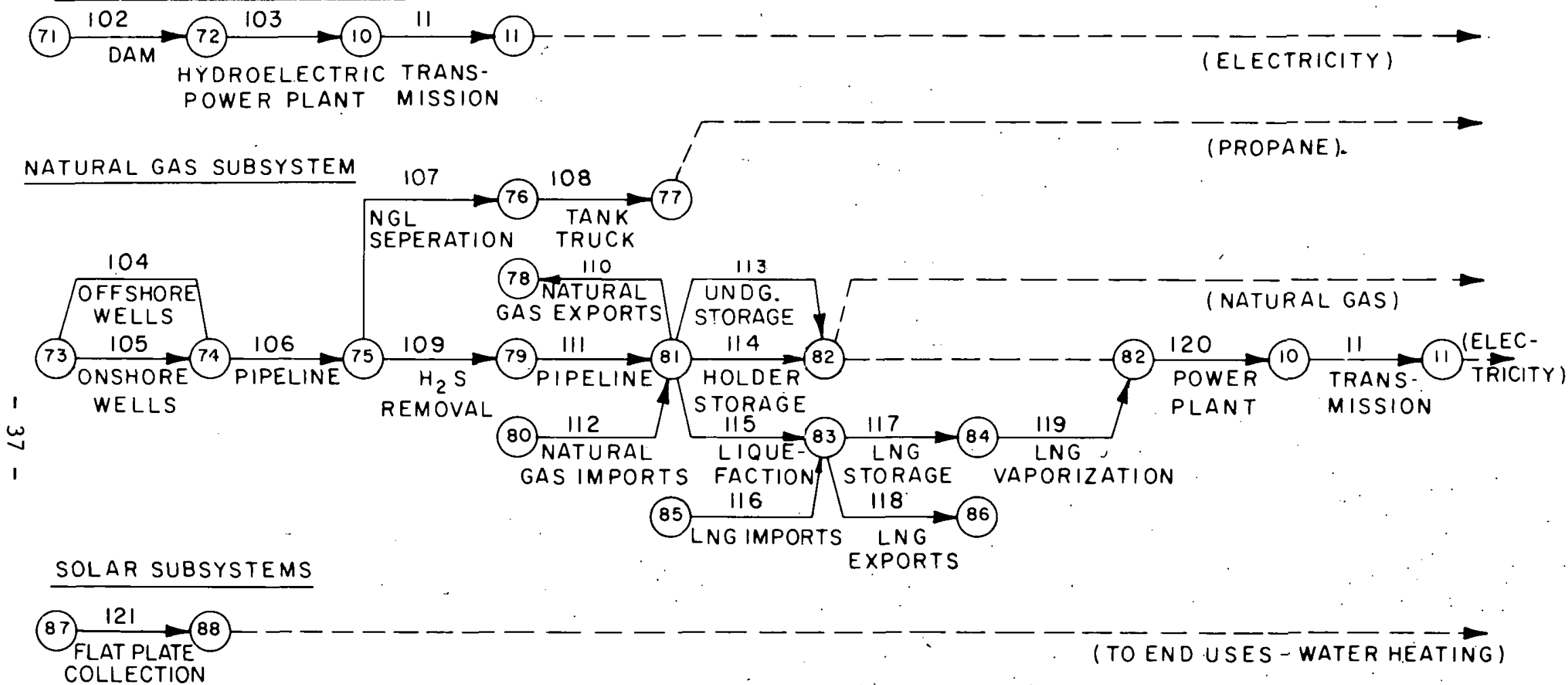

$$
\begin{aligned}
& \text { COLLECTION }
\end{aligned}
$$

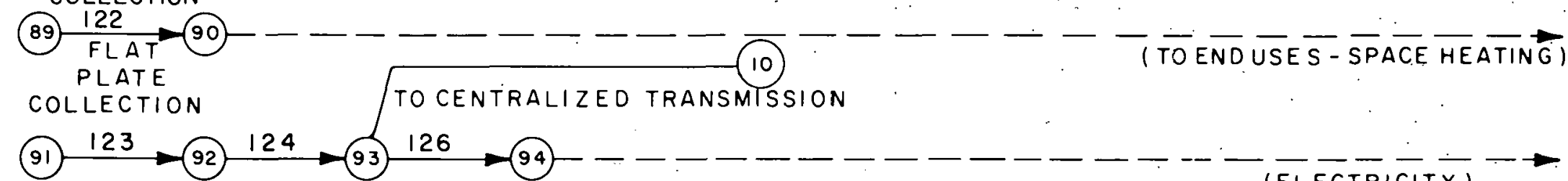

PHOTOVOLTAIC BATTERY DECENTRALIZED

COLLECTOR STORAGE TRANSMISSION 
$\underset{\infty}{\omega}$
FROM COAL LIQUEFACTION (CSF)

OR COAL LIQUEFACTION (SRC)

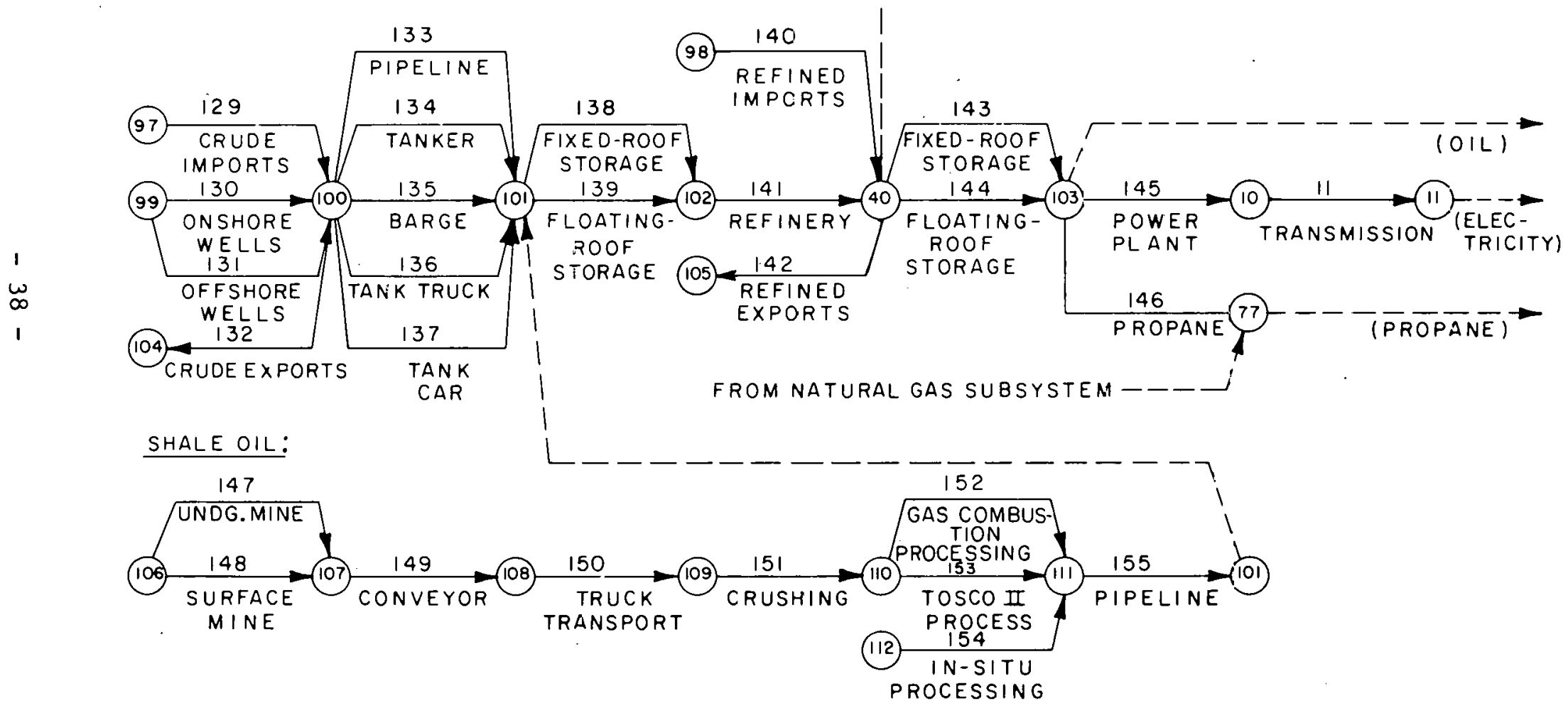



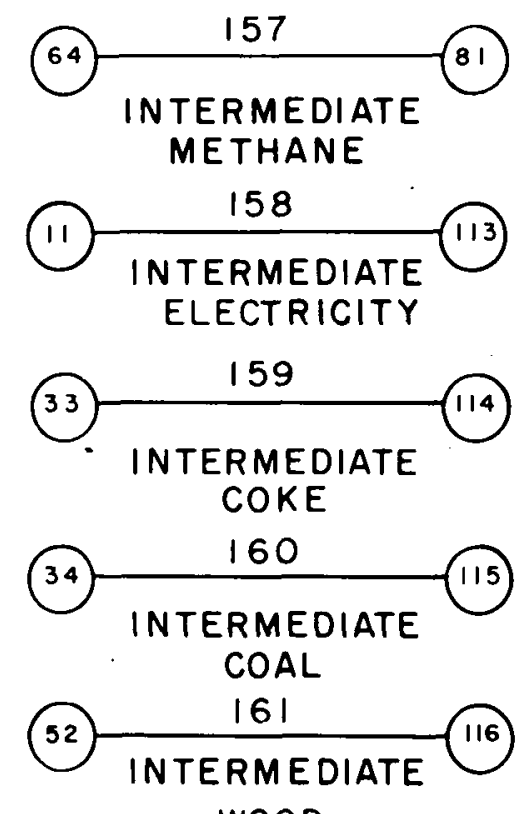
WOOD

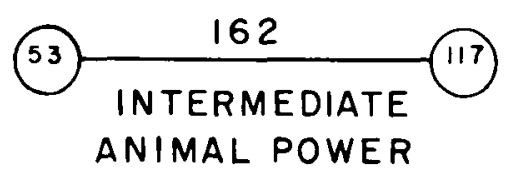

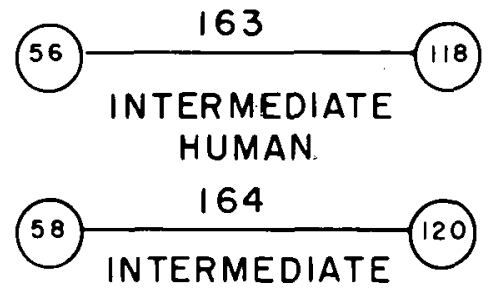

DRIED AGRIC. RESID.

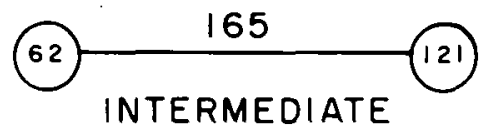

DRIED ANIMAL RESID.

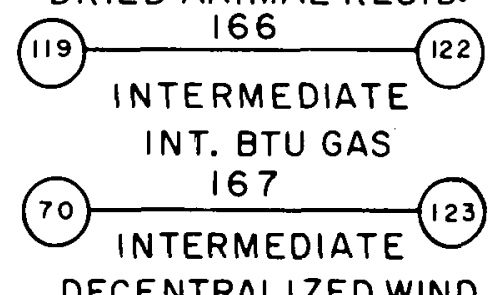

DECENTRALIZED WIND

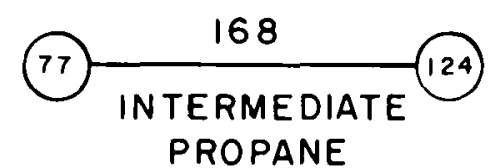

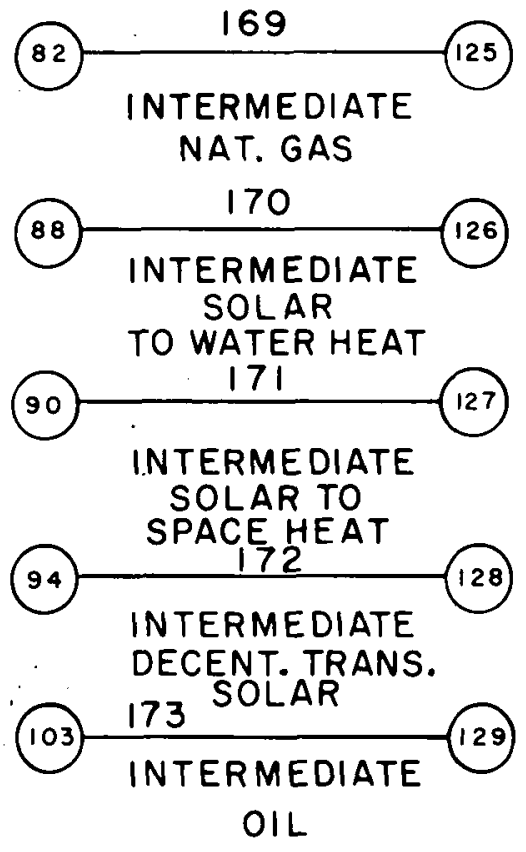




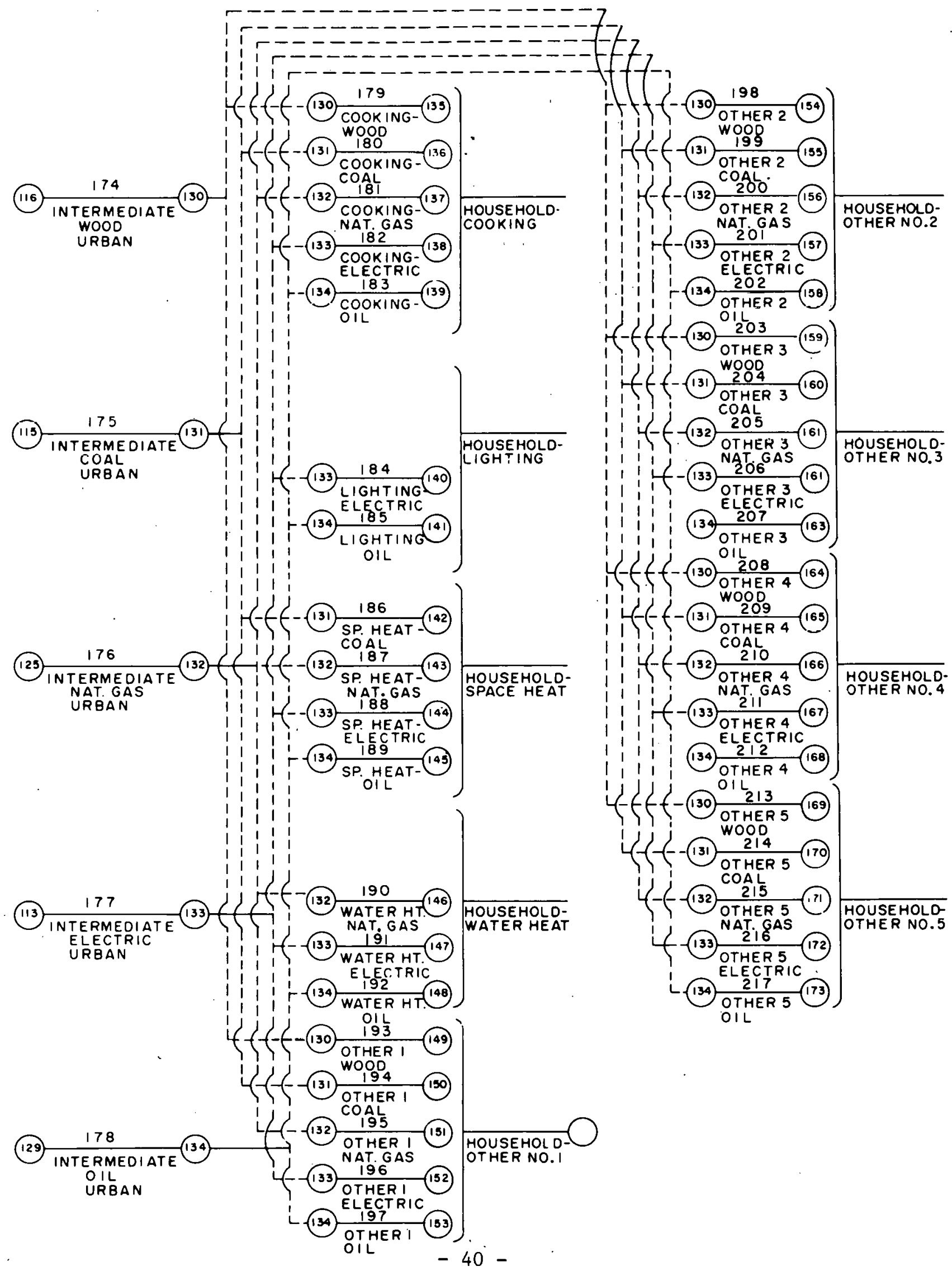




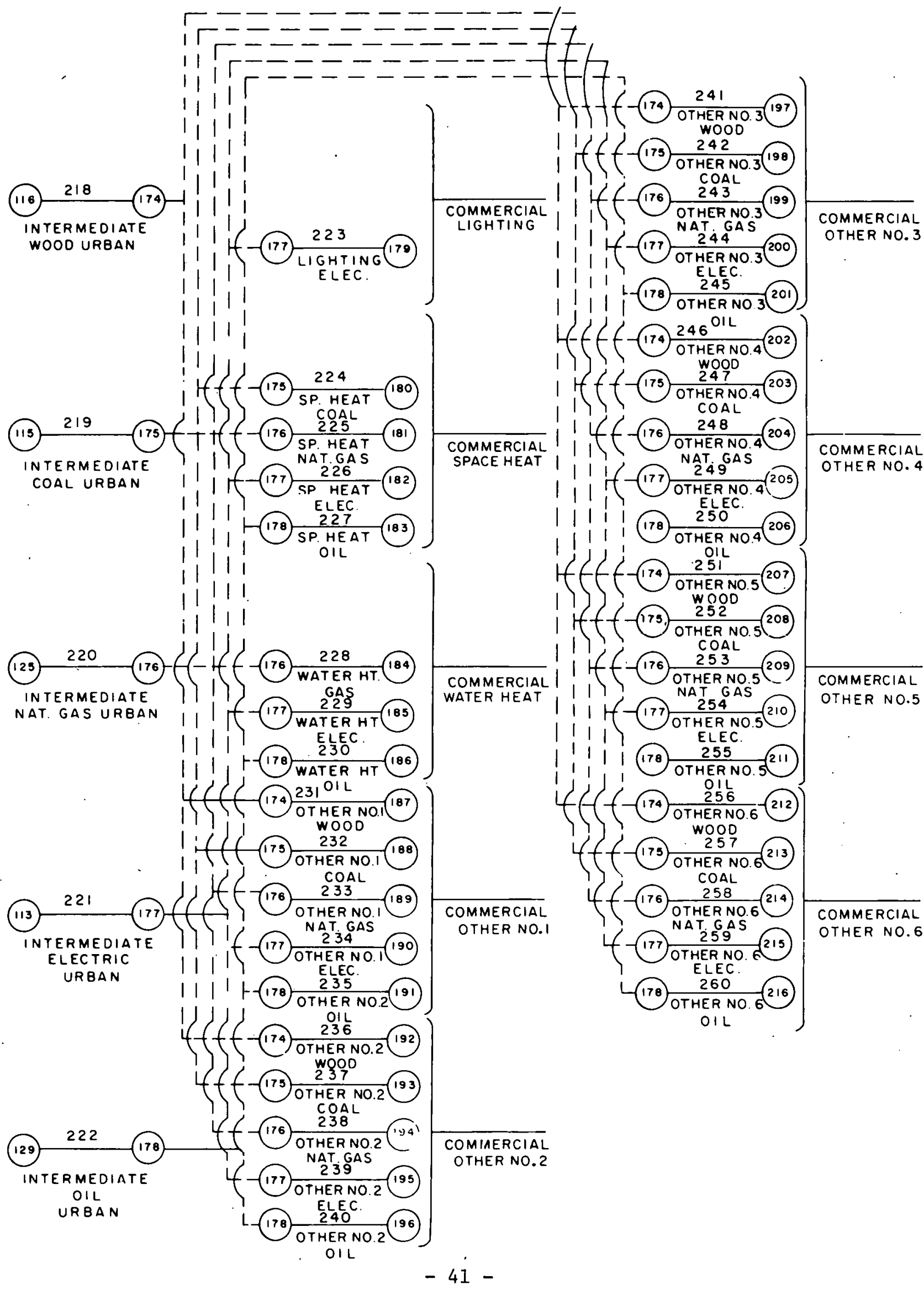


LDC-ESNS UTILIZATION PROCESS

NETWORK - RURAL
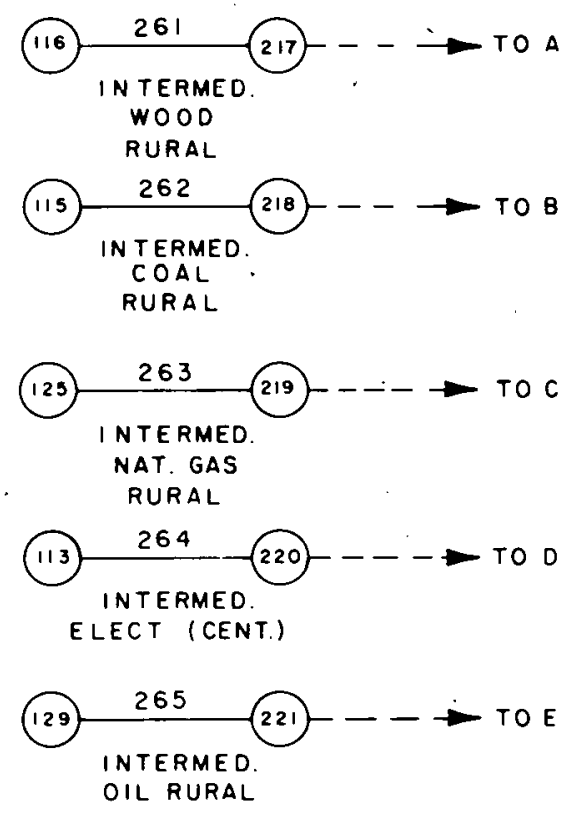

(121) 266 TOF INTERMED

ANIMAL WASTE RURAL

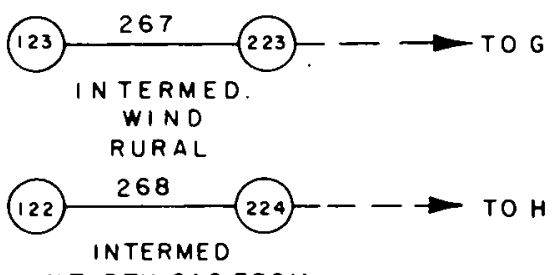

INT. BTU GAS FROM

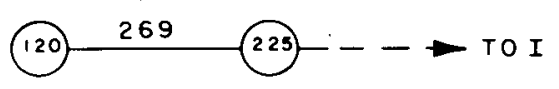

INTERMED

AGRICULTURAL

RESIOUALS

RURAL

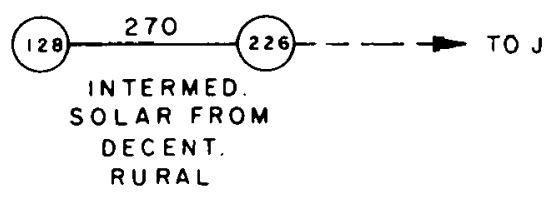

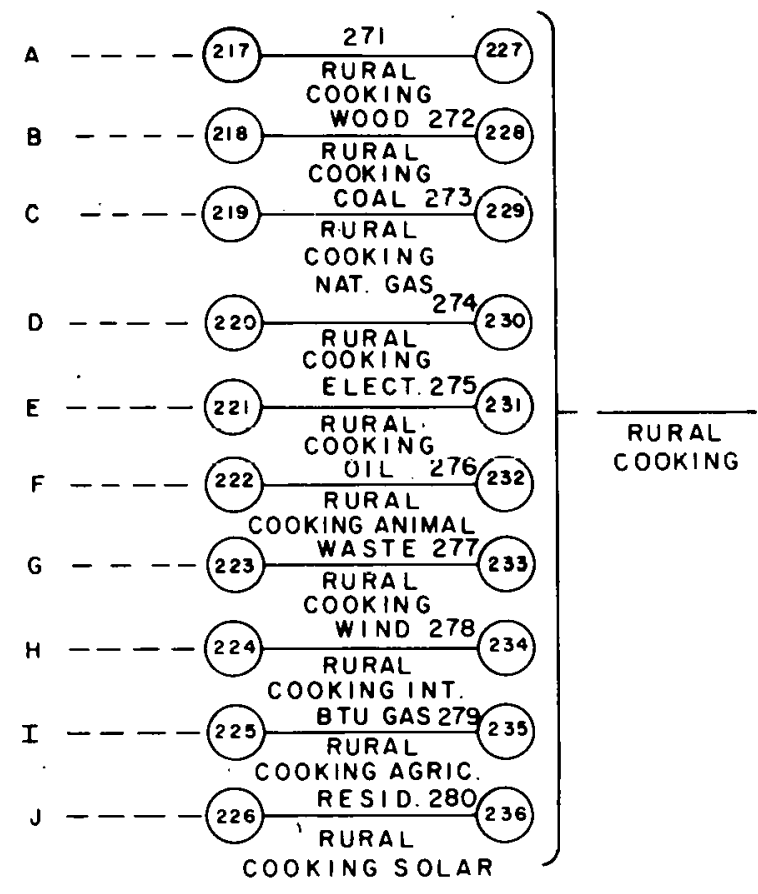



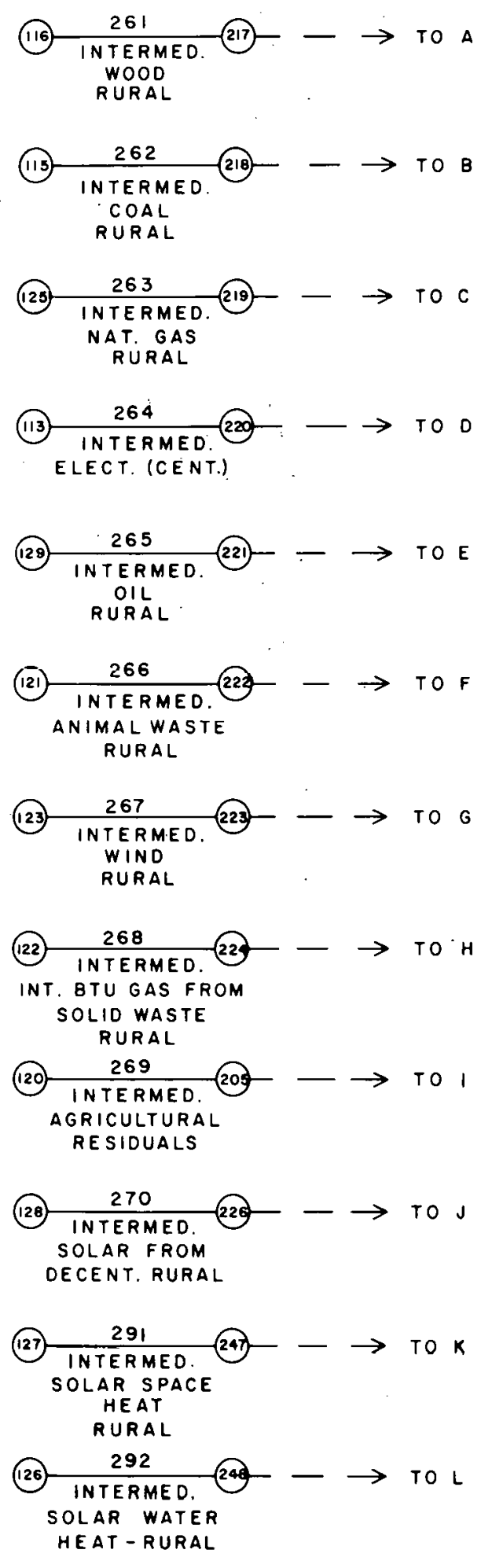

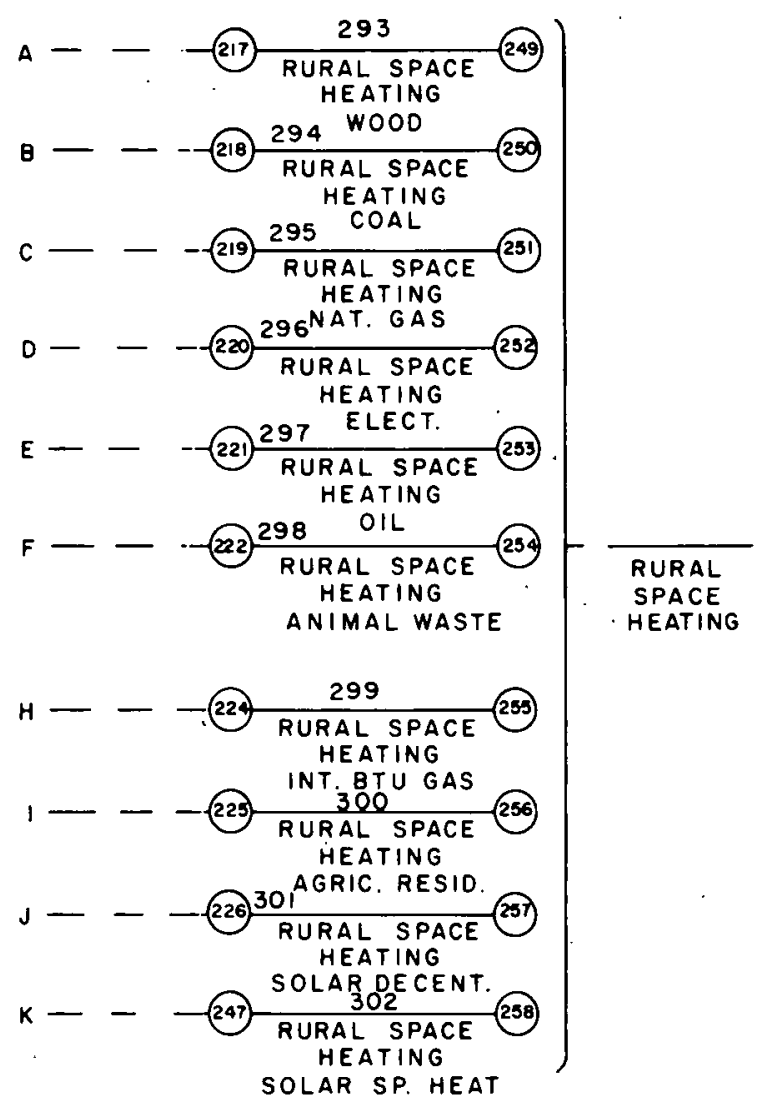

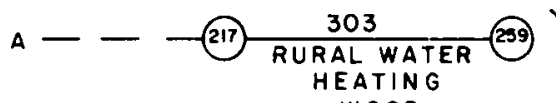$$
8-218 \text { WOOD } 304
$$$$
\text { HEATING }
$$$$
C-219 \frac{305 \text { COAL }}{\text { RURAL WATER (261) }}
$$$$
\text { HEATING }
$$$$
D--220 \frac{306^{\text {NAT. GAS }}}{\text { RURAL WATER }}
$$$$
\text { HEATING }
$$$$
\text { E- 221 } \frac{307 \text { ELECT. }}{\text { RURAL WATER }}
$$$$
\text { HEATING }
$$$$
F-222 \frac{308 \text { OIL }}{\text { RURAL WATER }}
$$$$
\text { HEATING }
$$$$
\text { ANIMAL WASTE }
$$$$
H-224 \frac{309}{\text { RURAL WATER }}
$$$$
\text { HE ATING }
$$$$
1-223 \frac{310^{I N T .8 T U} \text { GAS }}{\text { RURAL WATER }}
$$$$
J-\text { (26) } \frac{31 I^{A G R I C . R E S I D .}}{\text { RURAL WATER }}
$$$$
\text { HEAT ING }
$$$$
\mathrm{L}--\frac{312 \text { SOAARDECENT. }}{\text { RURAL WATER }}
$$

RURAL

WATER

HEATING 
(116) INTERMED.
INOOD
RURAL

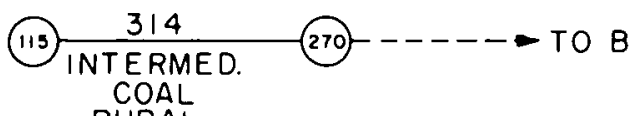
RURAL

315
INTERMED.
NAT.GAS RURAL

(113) $\frac{316}{\text { INTERMED. } 272-----1 O D}$
ELECT. (CENT.)

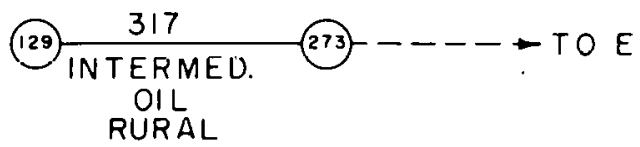
(12) $\frac{318}{\text { INTERMED. } 274----\rightarrow T O F}$
AN IMAL WASTE RURAL
(123) $\frac{319}{\text { INTERMED. 275---- }}$ WIND RURAL
(122) $\frac{320}{\text { INTERMED. }}$ (276- $--\rightarrow \mathrm{TO} \mathrm{H}$ INT. BTU GAS FROM
SOLID WASTE
(120) $\frac{321}{\text { INTERMED. }}$ (277) $-\rightarrow$ TO I AGRICULTURAL
RESIDUAL_S RURAL
(118) $\frac{326}{\text { IN TERMED }}$ (282)-- $\rightarrow$ TO N HUMAN POWER RURAL

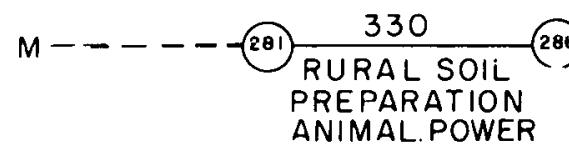
N-D- - 282
RURAL SOIL PREPARATION HUMAN POWER

(200) $\frac{332}{\text { FEED STOCKS }}$ COAL
C- $---171 \frac{333}{\text { FEED STOCKS }}$ NAT. GAS

RURAL

SOIL

PREPARATION

FEEDSTOCKS

$$
E-----\sqrt[2733]{\frac{334}{\text { FEED STOCKS }} 290}
$$




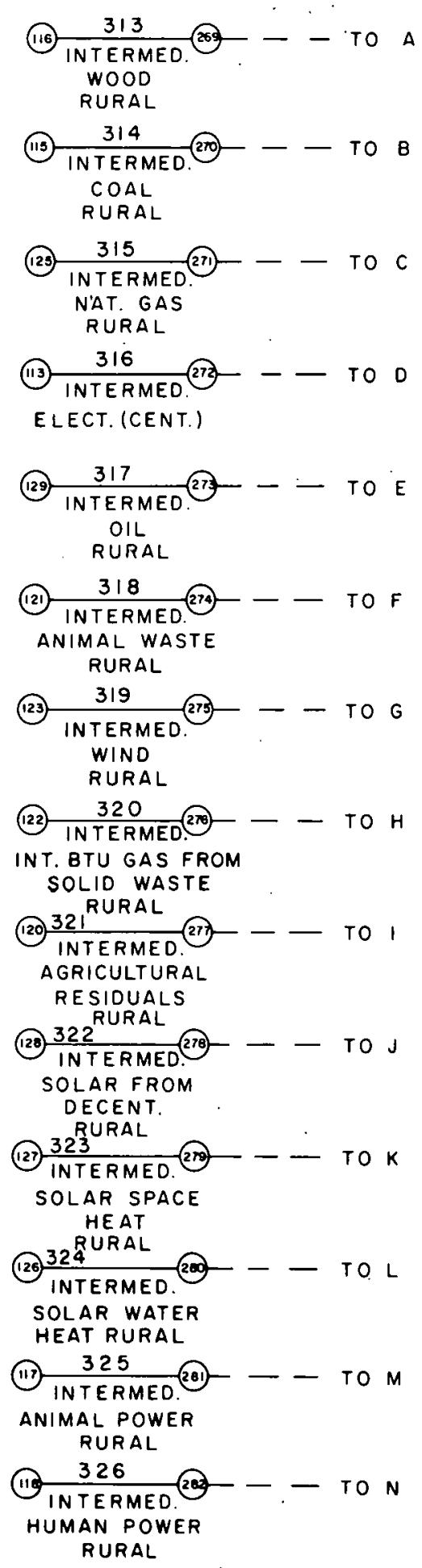

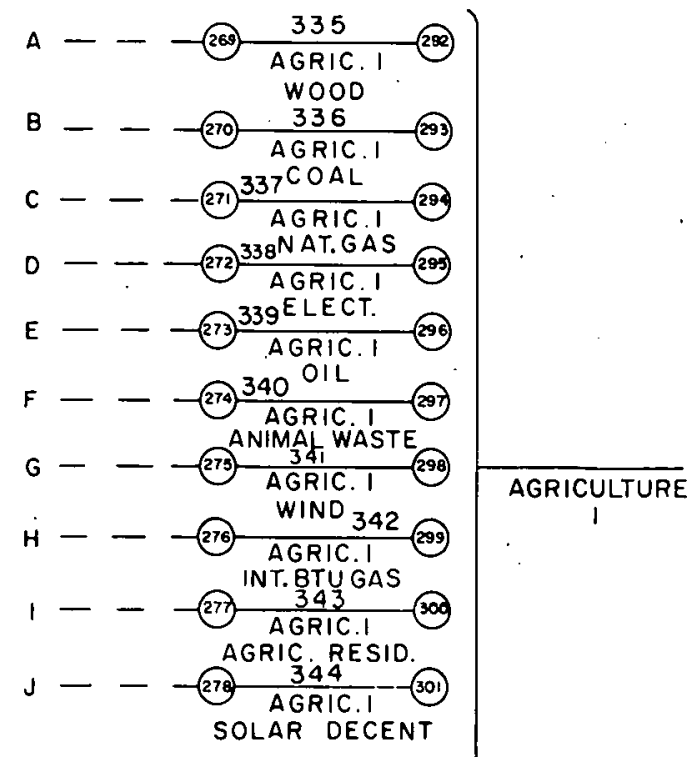

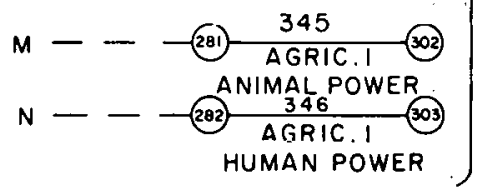

$A--\frac{347}{A G R I C .2}$

$B--7 \frac{348 W O O D^{\circ}}{A G R I C .2}$

$c-12 \frac{349^{C O A L}}{A G R I C .2}$

$0--2 \frac{350^{N A T} \cdot \dot{G A S}}{A G R I C .2}$

$E--(23) \frac{351 E L E C T .}{A G R I C .2}$

$F--7 \frac{352 \text { OIL }}{A G R I C, 2}$

$G--\frac{\text { ANIMALWASTE }}{\text { AS3 }}$

$H---\frac{354 \text { WIND }}{A G R I C .2}$

$1--2 \frac{\mid N T . B_{3 H} T \text { GAS }}{A G R I C .2}$ AGRIC RESID.

$\mathrm{J}-\mathrm{-170} \frac{356}{A G R I C .2}$ SOLAR DECENT 


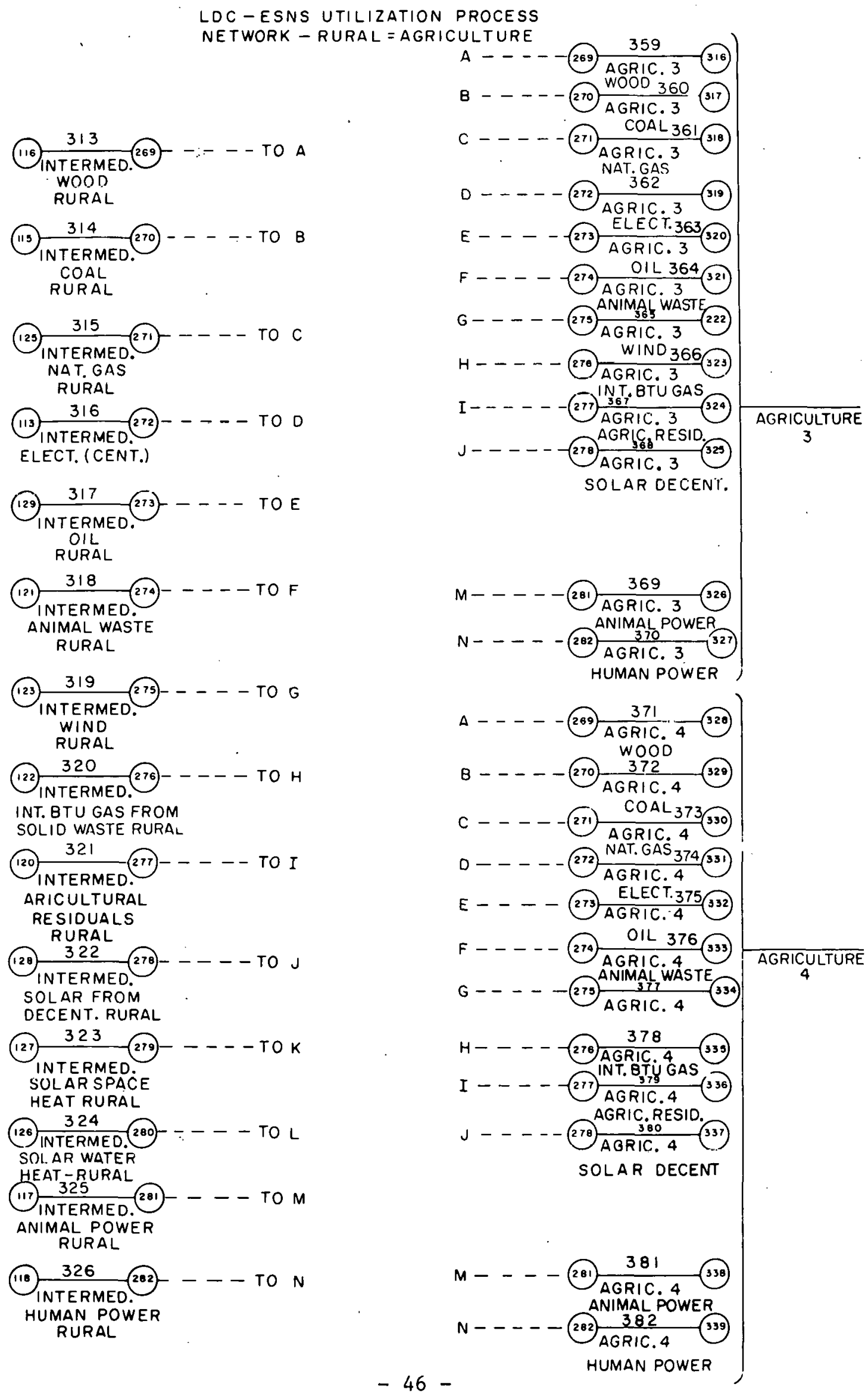




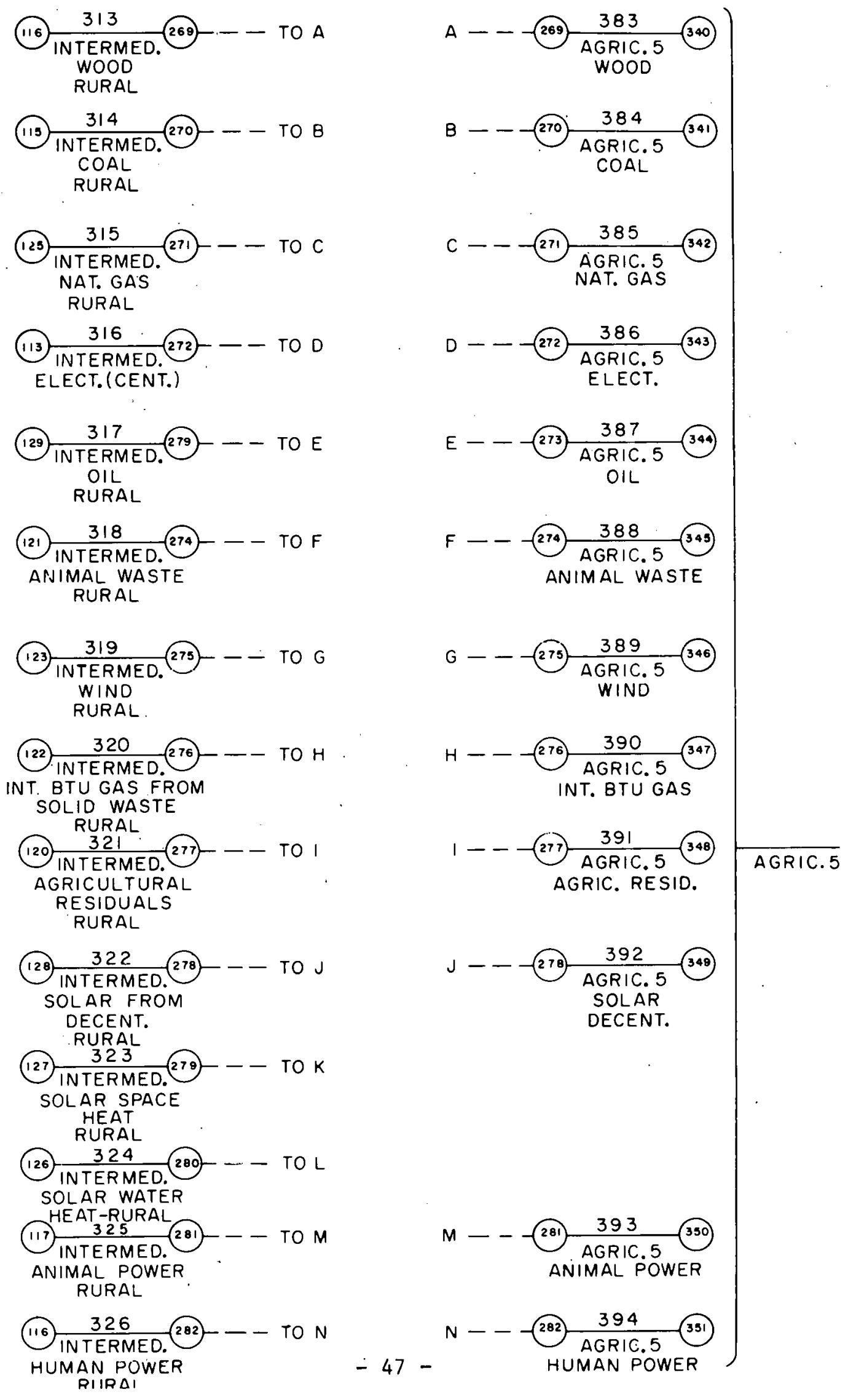




$$
\begin{aligned}
& \text { (116) INTERMED. } 352 \text { - } 395 \\
& \text { WOOD RURAL }
\end{aligned}
$$

$$
\begin{aligned}
& \text { (115) } \\
& \text { INTERMED. } \\
& \text { COAL RURAL }
\end{aligned}
$$

$$
\begin{aligned}
& \text { (125) } 397 \\
& \text { INTERMED. } 359 \\
& \text { NAT. GAS RURAL }
\end{aligned}
$$$$
\begin{aligned}
& \text { (113) } \frac{398}{\text { INTERMED. }} \text { (355) } \\
& \text { ELECT. (CENT) }
\end{aligned}
$$$$
\text { 129) } 399
$$$$
\text { (121) } \frac{400}{\text { INTERMED. 357) }---T O F}
$$$$
\text { ANIMAL WASTE }
$$$$
\text { RURAL }
$$

(123) $\frac{401}{\text { INTERMED. }}$ (358)- - -TO G WINO RURAL.

$$
\begin{aligned}
& \text { (122) INTERMED. } 350---- \text { TO H } \\
& \text { INT. BTU GAS FROM }
\end{aligned}
$$
SOLID WASTE RURAL

$$
\begin{aligned}
& \text { (120) } \frac{403}{\text { INTERMED. }} 360--- \text { TO I } \\
& \text { ARICULTURAL } \\
& \text { RESIDUALS RURAL }
\end{aligned}
$$

$$
\begin{aligned}
& \text { (128) } 404 \text { INTERMEO. (361) - - TOJ } \\
& \text { SOLAR FROM DECENT. } \\
& \text { RURAL } \\
& \text { (127) } 405 \text { INTERMED.362- - - -TO K } \\
& \text { SOLAR SPACE HEAT } \\
& \text { RURAL } \\
& \text { (126) } 406 \text { INTERMED. } 363--T O L \\
& \text { SOLAR WATER HEAT } \\
& \text { RURAL. } \\
& \text { (117) } 407 \text { INTERMEO. 364- - TO M } \\
& \text { HUMAN POWER } \\
& \text { RURAL } \\
& \text { (118) } \frac{408}{\text { INTERMED. } 365-}-- \text { TO } N \\
& \text { ANIMAL POWER } \\
& \text { RURAL }
\end{aligned}
$$

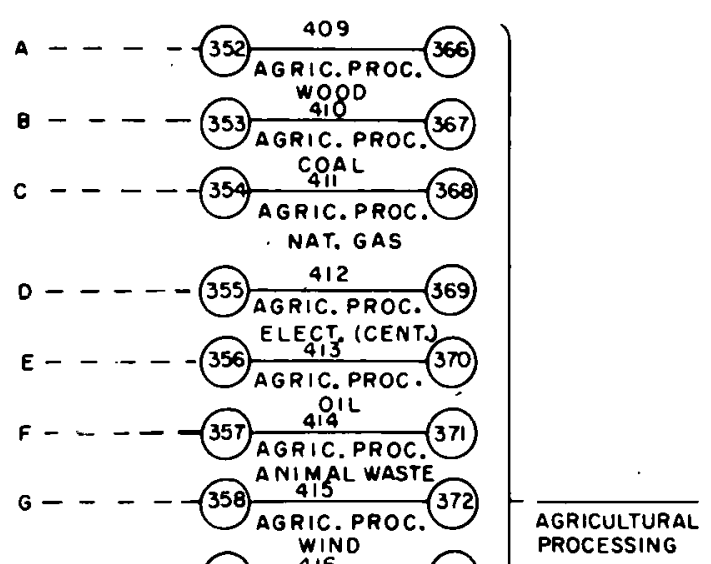

$I----360 \frac{417}{374}$

$J----361 \frac{A G R I C . R E S .}{4 G R I C . P R O C .}$ SOLAR DECENT.

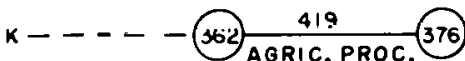

$L---(363)_{\text {AGRIC. PROC. }}^{\text {SOLAR }}$ SOLAR WATER

MEAT

$M---1364 \frac{421}{A G R I C . \text { PROC. }} 378$

$N-D--365$ AGRIC. PROC. 379 ANIMAL POWER

A - - - (352) $\frac{42.3}{\text { HANO.PROD. } 380}$ WOOD

B - - (353) $\frac{424}{\text { HAND.PROD. } 381}$

c - - - - (354) $\frac{\text { COAL }}{\text { HAND.PROD. }}$

D - - - (355) NAT. GAS 426 HAND. PROD. 383

E - - - (356) $\frac{\text { ELECT. }{ }_{4} \& E N T \text { HAND.PROD. }}{384}$

F - - - (357) $\frac{428}{\text { HAND.PROD. }}$

G - - - (358) $\frac{\text { ANIMALWASTE }}{\text { HAND.PROD. }}$

WIND

H $-359 \frac{430}{\text { HAND.PROD. } 387}$

$I---=\frac{431}{\text { HANO.PROD. }}$

J- - - - (361) $\frac{\text { AGRIC.R2RES. }}{\text { HAND.PROD. }}$ SOLAR DECENT.

$K----(362) \frac{433}{\text { HAND.PROD. } 390}$ SOLAR SPACE

MEAT

L- - - - 363 HAND.PROO. 391 SOLAR WATER

HEAT

$M-\ldots-D 364 \quad 435$

HAND. PROD. HUMAN POWER 
LDC-ESNS UTILIZATION PROCESS

NETWORK - RURAL
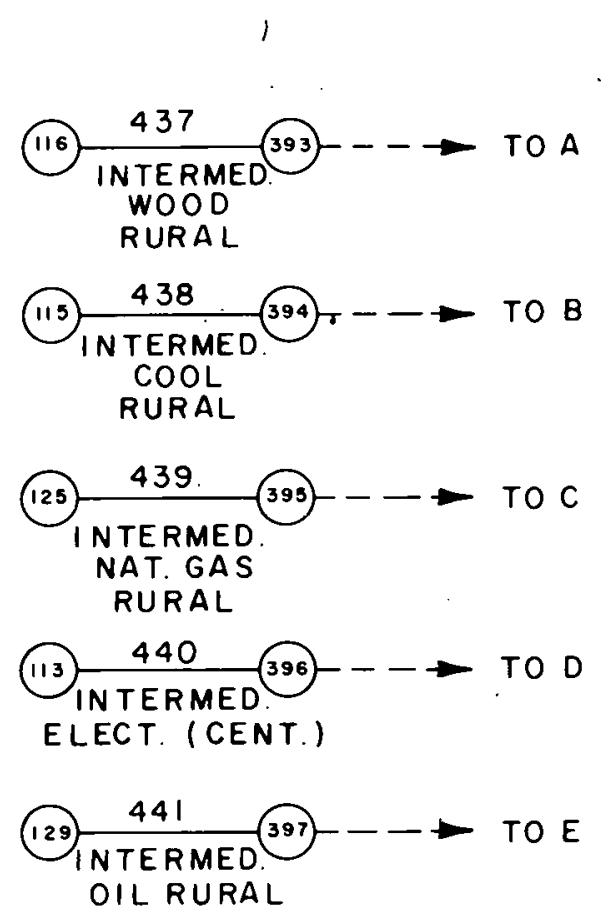

(121) $\frac{442}{\text { INTERMED }}-798$ TO F ANIMAL WASTE RURAL
(123) $\frac{443}{\text { IN TERMED }} \rightarrow$ TO G WIND RURAL

(122) $\frac{444}{\text { INTERMEO }}$ INT. BTU GAS

FROM SOLID WASTE

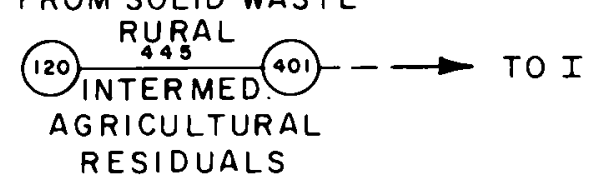
(128) $\frac{446}{\text { INTERMED }}$ T02 $--\rightarrow$ TO J SOLAR FROM
DECENT. RURAL
(127) $\frac{447}{\text { INTERMED }}$ - 03 - TO $\mathrm{K}$ SOLAR SPACE HEAT RURAL

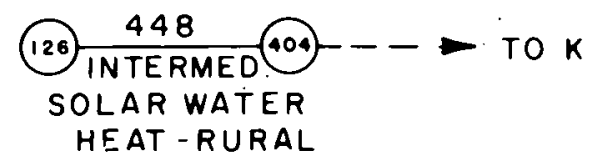

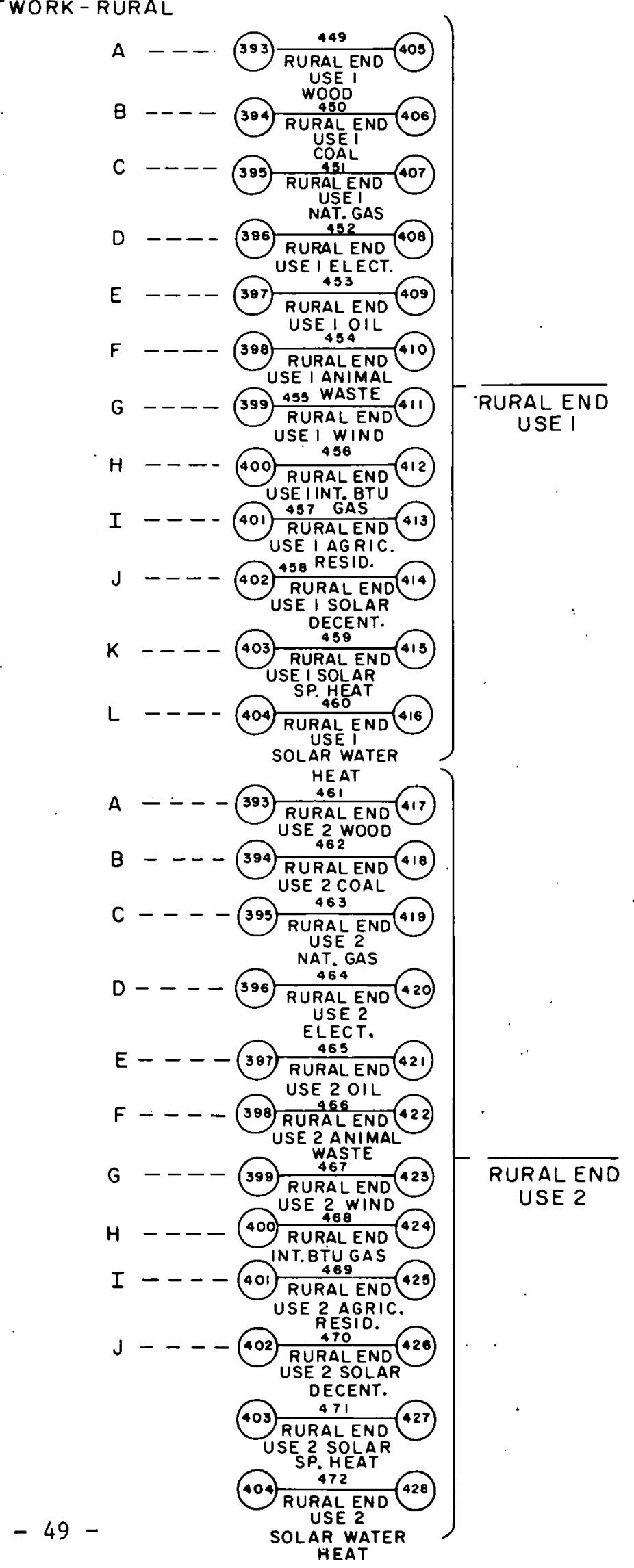


LDC - ESNS UTILIZATION PROCESS

NETWORK - RURAL

$$
\begin{aligned}
& \text { (110 } \\
& \text { INTERMED. } \\
& \text { WOOD } \\
& \text { RURAL }
\end{aligned}
$$

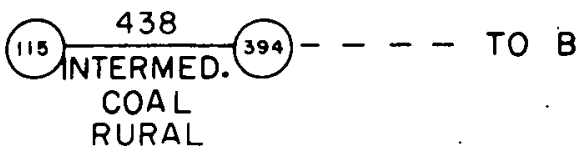
(125) $\frac{439}{\text { INTERMED. } 313}-\cdots--$ TO $C$ NAT. GAS RURAL

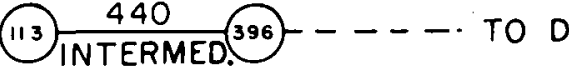
ELECT. ( CENT.)
(129) $\frac{441}{\text { INTERMED. } 397}-\cdots--$ TO E OIL RURAL
121 442 INTERMED $300--\cdots$ TOF ANIMAL WASTE RURAL
$123 \frac{443}{\text { INTERMED. } 399}-----$ TO G WIND RURAL

(122) $\frac{444}{\text { INTERMED } 400-----T O H}$ INT. BTU GAS FROM SOLID WASTE

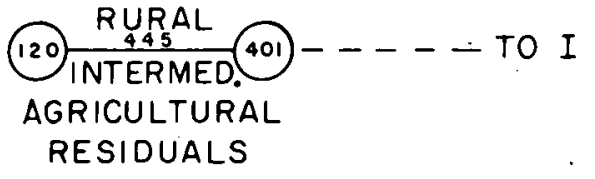
$128 \frac{446}{\text { INTERMED.402 }-\cdots--T O ~ J ~}$ SOLAR FROM
DECENT. RURAL

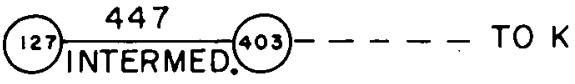
SOLAR SPACE HEAT

(128) $\frac{\text { RURARL }}{\text { INTERMED. (404) }}-\cdots--$ TO L SOLAR WATER
HEAT-RURAL

$$
\begin{aligned}
& A--\ldots-1393 \frac{473}{\text { RURALEND }} 420 \\
& \text { B- - - - (394) } \frac{474}{\text { RURALEND }} \text { USE } 3 \text { COAL } \\
& \text { C- - - - } 393 \text { RURALEND } 431 \\
& \text { D- - - - - (396) RURAL ENND } 432 \\
& \text { E - - - - (397) } \frac{\text { ELECT. }}{\text { RURAL END (433) }}
\end{aligned}
$$

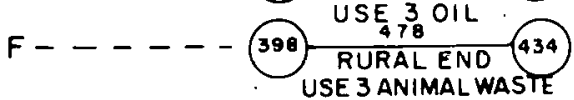

$$
\begin{aligned}
& \text { G - - - - } 390 \frac{479}{\text { RURALEND }} 435-\frac{}{\text { RURAL END }} \\
& H-1--1400 \text { RURALEND } 430 \\
& \text { I - - - - 401 GAI } 4 \text { RULEND } 437 \\
& \text { J-- - } 402 \text { RURAL END } 430 \\
& \text { DECENT. } \\
& K-1-1403 \text { RURALEND } 430 \\
& \text { L - - - } 404 \text { 494 HEAT } \\
& \text { USE } 3 \text { SOLAR } \\
& \text { WATER HEAT } \\
& \text { A - - - (393) } \frac{\text { RURALEND }}{\text { USE 4 WOOD }} \\
& B---1 \text { (394) RURALEND } 482 \\
& \text { C - - - - (393) } \frac{\text { USE } 4 \text { COAL COAL }}{\substack{\text { RURALEND } \\
\text { USE } 4}} \\
& 0---1396 \frac{\text { NAT.GAS }}{48 B} \\
& E-1397 \text { RURAL END } 445 \\
& \text { F - - - - } 398 \frac{\text { USE } 490 \text { OIL }}{\text { RURALEND }} \\
& \text { G- - - - (399) } \frac{491 \text { WASTE }}{\text { RURALEND } 447} \\
& \text { H- - - - (400) USE } 492 \text { WIND } \\
& \text { I - - - - } 401 \text { USE } 4 \text { INT. BTU GAS } \\
& J--1402 \frac{\text { RESID. }}{494} \text { RURALEND } 400
\end{aligned}
$$

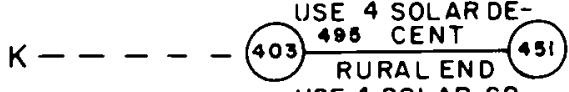

$$
\begin{aligned}
& \text { USE } 4 \text { SOLAR SP. } \\
& \text { L- - - - 404 } \frac{496 \text { HEAT }}{\text { RURAL END } 452} \\
& -50- \\
& \begin{array}{l}
\text { USE } 4 \text { SOLAR } \\
\text { WATER HEAT }
\end{array}
\end{aligned}
$$




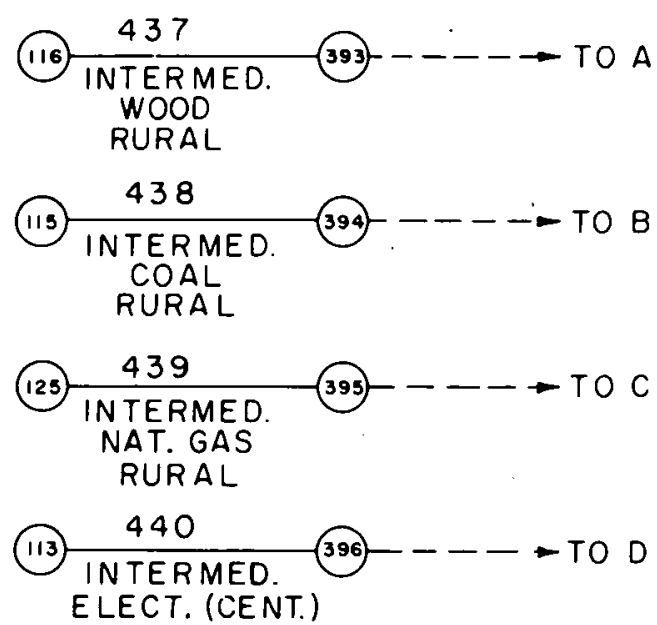
(129) $\frac{441}{\text { INTERMED. } 397}---$ TOE OIL RURAL
(121) $\frac{442}{\text { INTERMED. } 398--1}-1$ TOF ANIMAL WASTE RURAL
(123) $\frac{443}{\text { INTER MED. }}$ WIND
RURAL
(122) $\frac{444}{\text { INTERMED. }}$. $--7 \mathrm{TO}$ INT. BTU GAS FROM
SOLID WASTE
(122) $\frac{445}{\text { INTERMED }} \rightarrow$ (401) $\rightarrow$ TO I AGRICULTURAL RESIDUALS

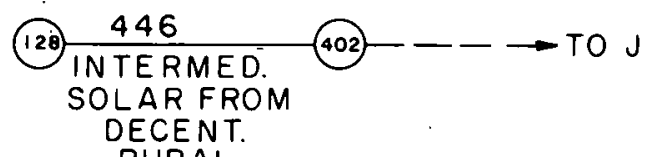

(127) $\frac{447}{\text { INTERMED. }}$ (403)- - SOLAR SPACE HEAT RURAL

(126) $\frac{448}{\text { INTERMED. (404) }}-\rightarrow$ TO L SOLAR WATER HEAT. RURAL

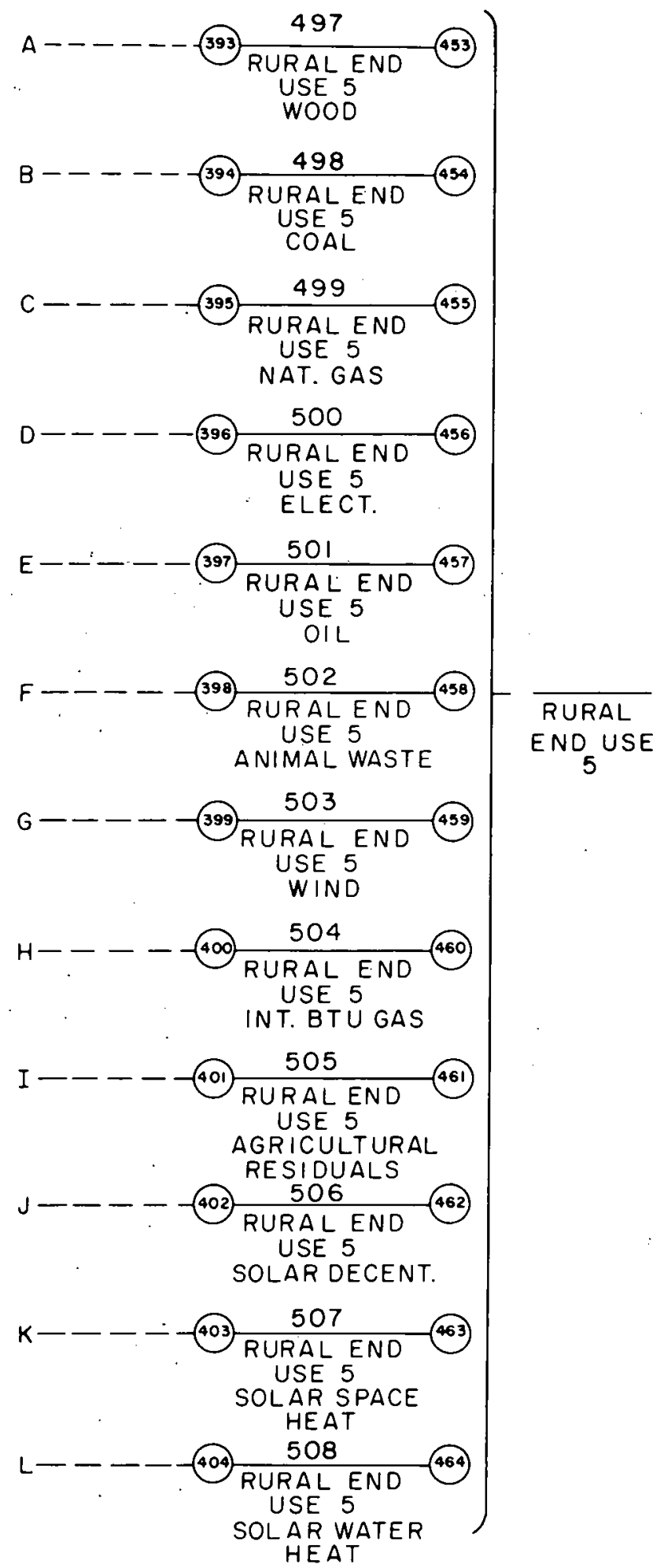

453 


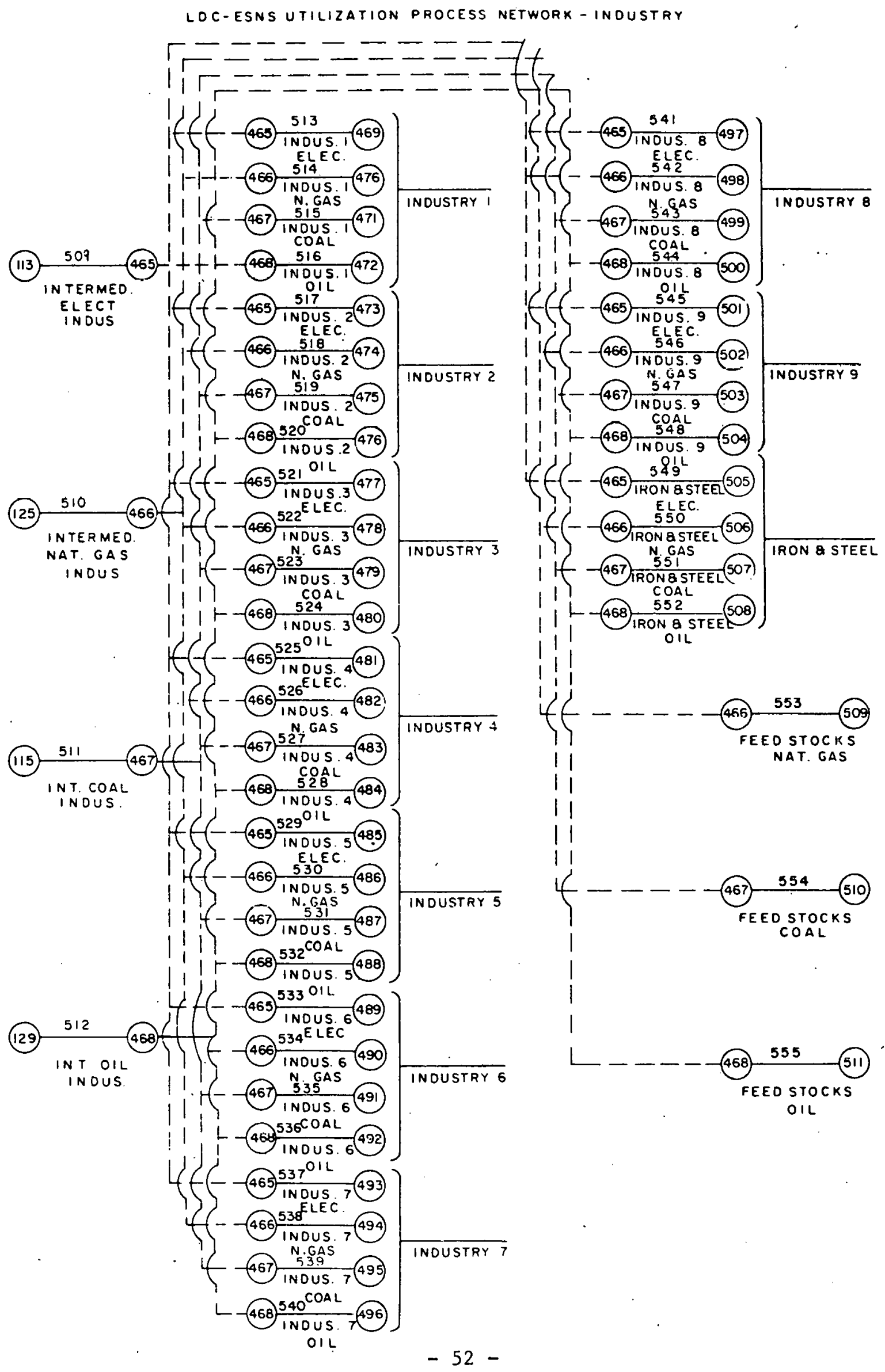


LDC-ESNS UTILIZATION PROCESS NETWORK-TRANSPORTATION

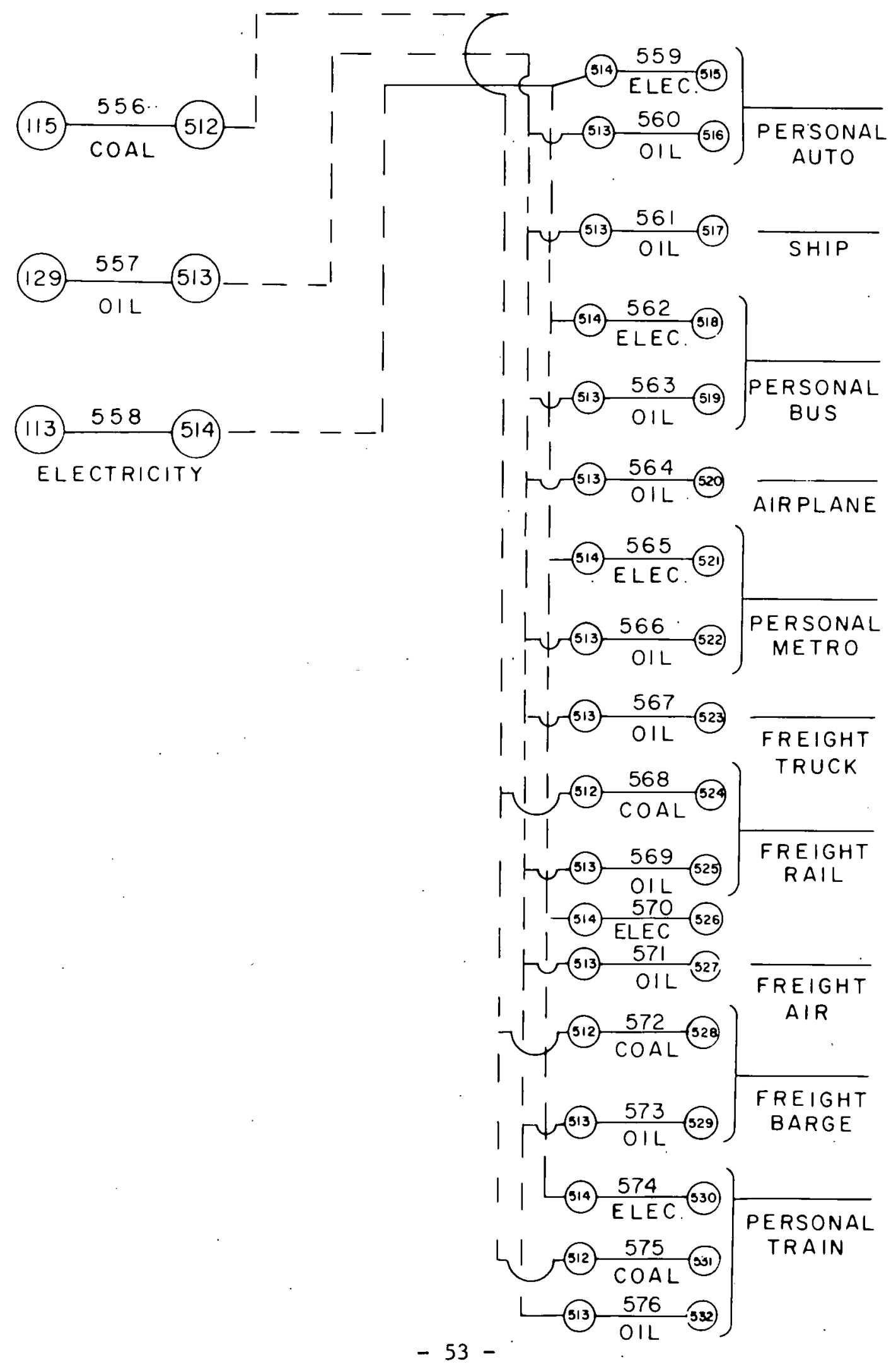


ITILIZATION

REFINING \& CONV.

IXTRACTION

REFINING \& CONV.

" $\quad$

CENIRAL STA, CONV

TRANS., DIST., STORAGE

CENIRAL STA, CONV.

EXTRACTION

"

REFINING \& COV.

$$
\begin{aligned}
& 1 " \\
& \text { " } \\
& \text { " } \\
& \text { 1" } \\
& \text { " } \\
& \text { 1" } \\
& \text { " }
\end{aligned}
$$

CENIRAL STA, CONY<smiles>[IH2]</smiles>

"

REFINING \& CONV.

$$
\text { " }
$$

REFINING \& CONV.$$
"
$$$$
\text { " }
$$

LINK NO. NUCLEAR, STORAGE, WASTE STORAGE

? NUCLEAR,DISPOSAL . WASTE DISPOSAL

3 NUCLEAR, REPROCESSING.HTGR SPENT FIIEL RE.PROCESSING

4 NUCLEAR, RECYCLE, RECOVEREO URANIUM-HTGR FUEL REPROCESSING

5 NUCLEAR, RECYCLL, PECOVEREO THORIUM-HTGR FUEL REPROCESSING

b NUCLEAR, MINING THORIUIM MINE

7 NUCLEAR,MILLING, THORIUMM MILL

a NIJCLEAR, ENHICHMENT,UFG PRODUCTION

9 NUCLEAR, FUEL FABFICATION,HTGR FUEL FABRICATION

10 NUCLEAR, POWER PLANT, HTGR POWEH PLANT

11 ELECTRICITY.TRANSMISSION

12 NUCLEAR, POWER PLANT, LMFBR POWER PLANT

13 NUCLEAR, (U+PU)PLUR POWER PLANT

14 NUCLEAR:MINING,OPEN PIT URANIUM MINE

15 NUCLEAR,MINING.MINING, UNDERGROUNO IIRANIIIM MINE

If NUCLEAR,MILLING,MILLING CONCENTRATION

17 NUCLEAR, PROCESSING, HYOROFLUNOR

19 NUCLEAR,PROCESSING.SCLVENT EXTRACTION

19 NUCLEAR,ENRICHMENT,GASEOUS DIFFUSION

20 NUCLEAR, ENRI CHMENT,GAS CENTRIFUGE

21 NUCLEAR,ENRICHMENT, ENRICHMENT PYPASS

22 NUCLEAR, (11+PU)PWR FUEL FARRICATION

23 NUCLEAR,FUEL FAURICATION.LWR FLIEL FABRICATION

24 NUCLEar, POWER PLANT, (UtPU) BWR POWER PLANT

25. NUCLEAR, PUWER PLANT, PWR POWEF PLANT

2A NIICLEAR, POWER PLANT, HWR POWEP PLANT

27 NUCLEAR.REPROCESSING.LWR SPENT FUEL REPPOCESSING

2A NUCLEAR,REPROCESSING, (U+PUILLR SPENT FIJFL REPROCESSING

29 NUCLEAR,STORAGE,TAILS STIDRAGE

30 NUCLEAR, PARTITIOMING OYPASS

31" NUCLEAH, PARTITIONING, PARTITIONING

3? NUCLEAR, HECYCLE, UHANIUM QECYELE
NODE ORIG. NODE DEST. LINKS IN PARALLEI

578

478

458

457

121324252639596061677480 $8794100103120125128 \quad 145$

$1013242526 \quad 39596061677480$ 8794100103120125128145

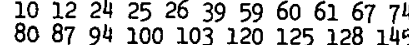
15

14

1832

1732

202133

192133

192021

1012132526395960616774

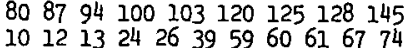

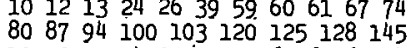

1012132425395960616774

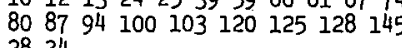

2734

31

30

1718 


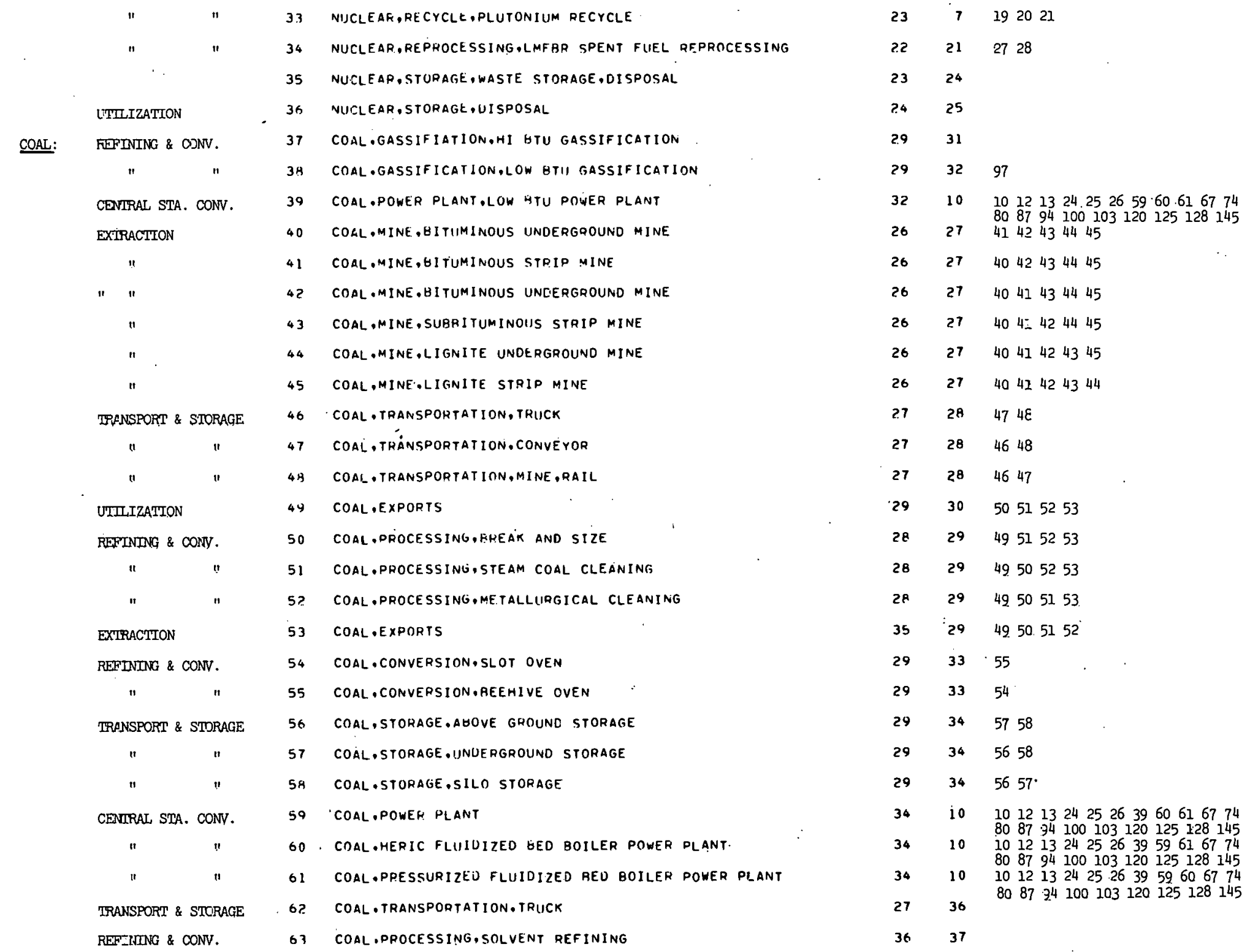




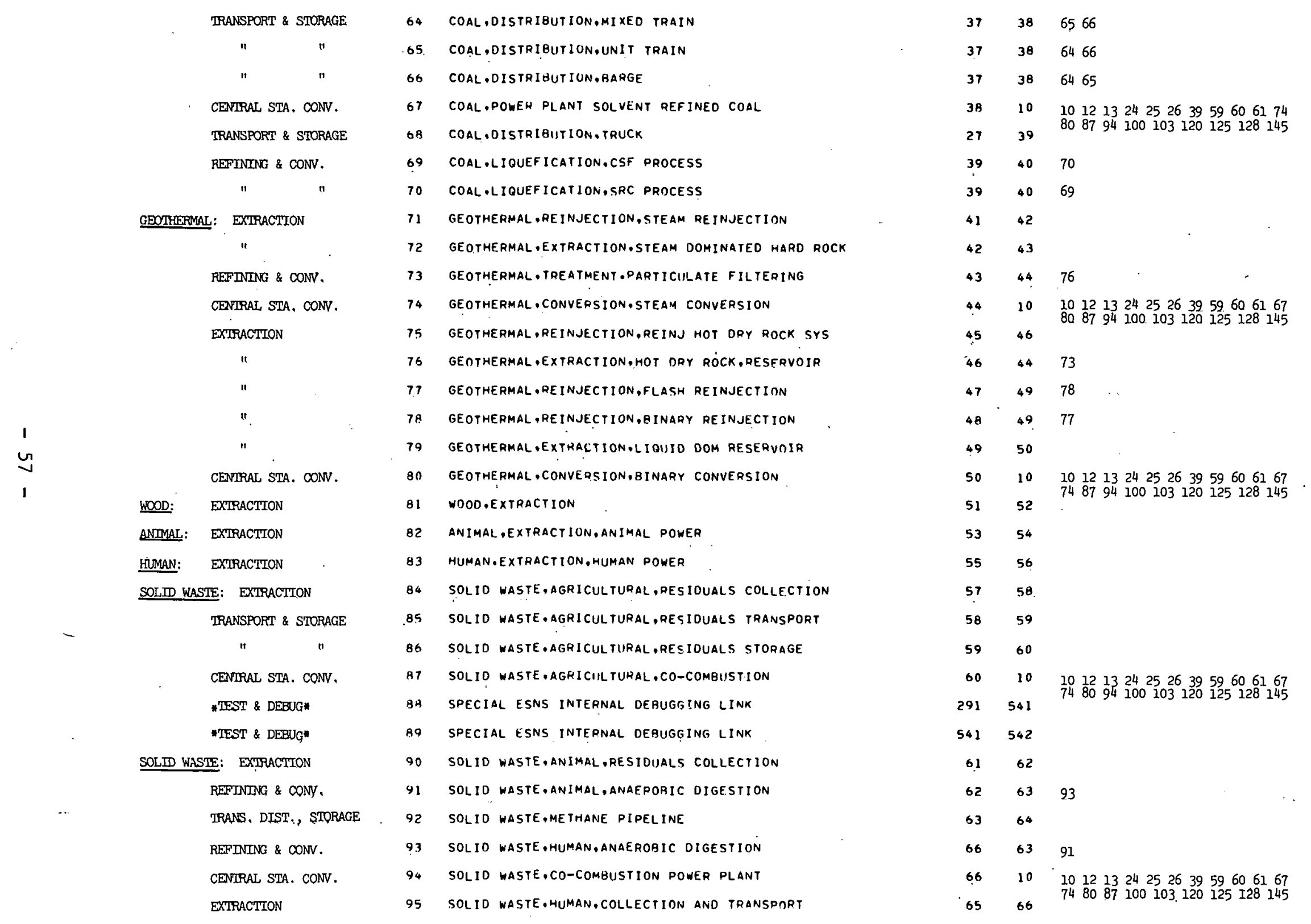




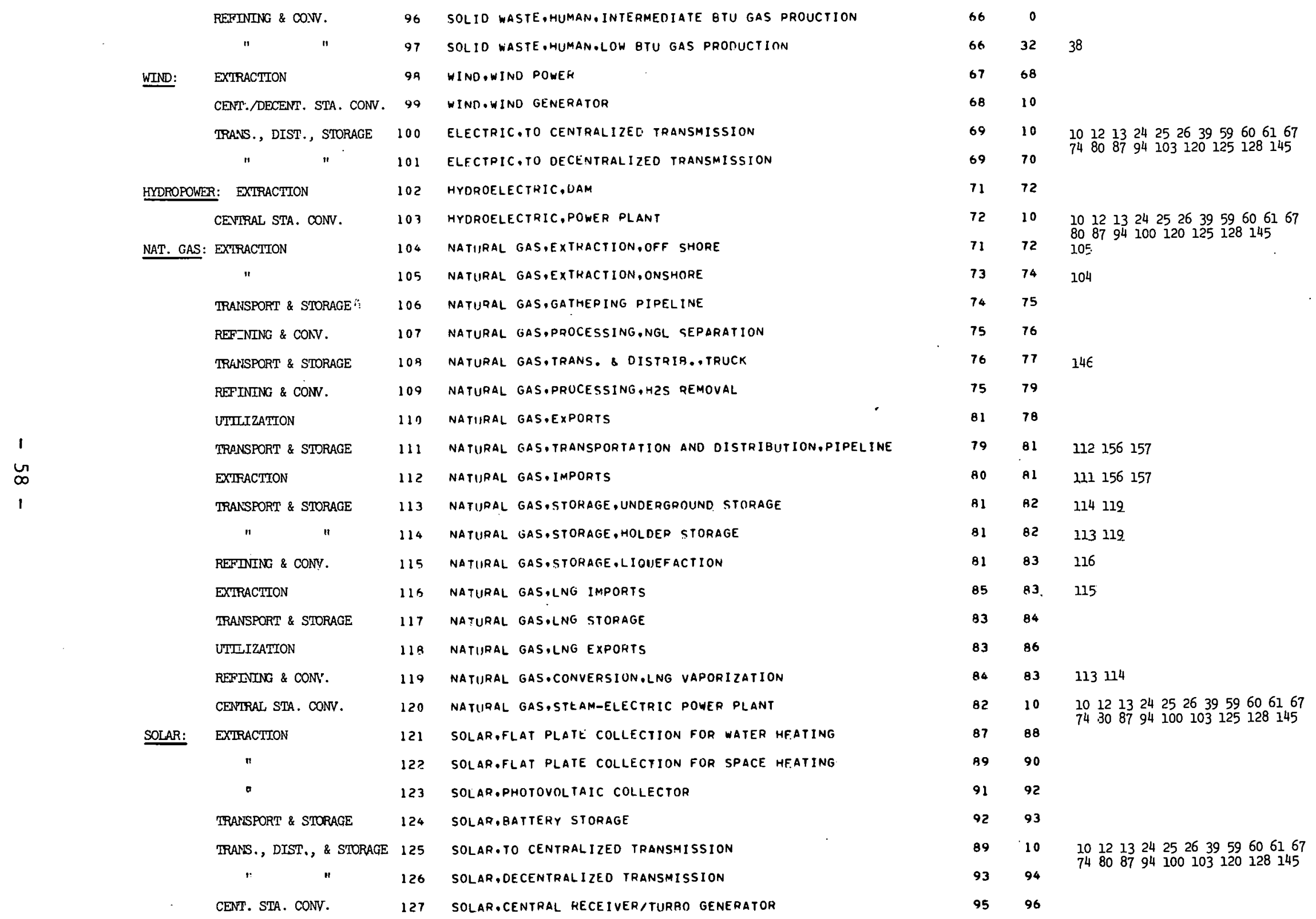


IRAN., DIST., \& STORAGE

에:

XXIRACITION

UTIIIZATION

TRANSPORT \& STORAGE

"

"

"

"

"

"

EXTRACTION

REF'INDNG \& CONV.

UTILIZATION

TRANSPORT \& STORAGE

$"$ "

CENIRAL STA. CONY.

TRANS., DIST., STORAGE

OII (SHALE): EXTRACTTON

TRANSPORT \& STORAGE

" $"$

REFINING \& CONY,

"

"

TRANSPORT, DIST., STOR.

NAT. GAS: TRANSPORT, DIST., STOR.

"

"
SOLAR.TO CENTRALIZEO TRANSMISSION

OIL.CRUDE IMPORTS

OIL,EXTRACTION.ONSHOPE WELLS

OIL, EXTRACTION,OFFSHORE WELLS

OIL, CRUDE IMPORTS

OIL, TRANSPORTATION, PIPE LINE

OIL.TRANSPORTATION, TANKER

OIL.TPANSPORTATION. BAPGE

OIL. TRANSPORTATION. TANK TFUCK

OIL, TRANSPORTATION, TANK CAR

OIL.STORAGE,FIXEO-ROOF STORAGE

OIL.STORAGE,FLOATING-FOOF STORAGE

OIL.REFINED IMPORTS

OIL.REFINING

OIL, REFINEO EXPORTS

OIL.STORAGE OFI XED. ROOF STORAGE

OIL.STORAGE, FLOATING-ROOF STORAGE

OIL.OIL FIAED POWER PLANT

OIL.DISTRIGUTION, PROPANE ALLOCATION

OIL, SHALE. UNDERGROUND MINE

OIL. SHALE. SURFACE MINE

OIL, SHALE, TRANSPORTATION. CONVEYOR

OIL. SHALE, TRANSPORTATION, TRIICK

OIL.PREPROCESSING CRUSHING

OIL. PROCESSING,GAS COMAUSTION

OIL, PROCESSING, TOSCO II

OIL, PAOCESSING, IN-SITU

OIL.DISTRIBUTION.PIPELINE

NATURAL GAS,PIPELINE FROM HI GTU GASSIFICATION

ME THANE, INTERMED I ATE

ELECTRIC, INTERMEDIATE

COKE, INTERMEDIATE
97

99

$99 \quad 100 \quad 129130$

$100 \quad 104$

$100 \quad 101$

$100 \quad 101 \quad 233135236237$

$\begin{array}{llll}100 & 101 & 133134136137\end{array}$

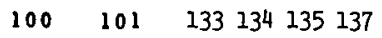

$\begin{array}{llll}100 & 101 & 133134135136\end{array}$

$101 \quad 102 \quad 139$

$101 \quad 102 \quad 138$

$98 \quad 40 \quad 6970141$

$102 \quad 40 \quad 6970140$

$40 \quad 105$

$40 \quad 103 \quad 144$

$40 \quad 103 \quad 143$

$\begin{array}{llllllllllll}103 \quad 10 & 10 & 12 & 13 & 24 & 2526 & 39 & 596061 & 67\end{array}$

$103 \quad 77 \quad 74808794100103120125128$

$106 \quad 107 \quad 148$

$106 \quad 107 \quad 147$

$107 \quad 108$

$108 \quad 109$

$109 \quad 110$

$110 \quad 111 \quad 153154$

$\begin{array}{lll}110 & 111 & 152154\end{array}$

$112 \quad 11 \quad 152153$

$111 \quad 101,133134135136137$

31 $81 \quad 111112157$

$\begin{array}{lllll}64 & 81 & 111 & 112 & 156\end{array}$

$11 \quad 113$

$33 \quad 114$ 


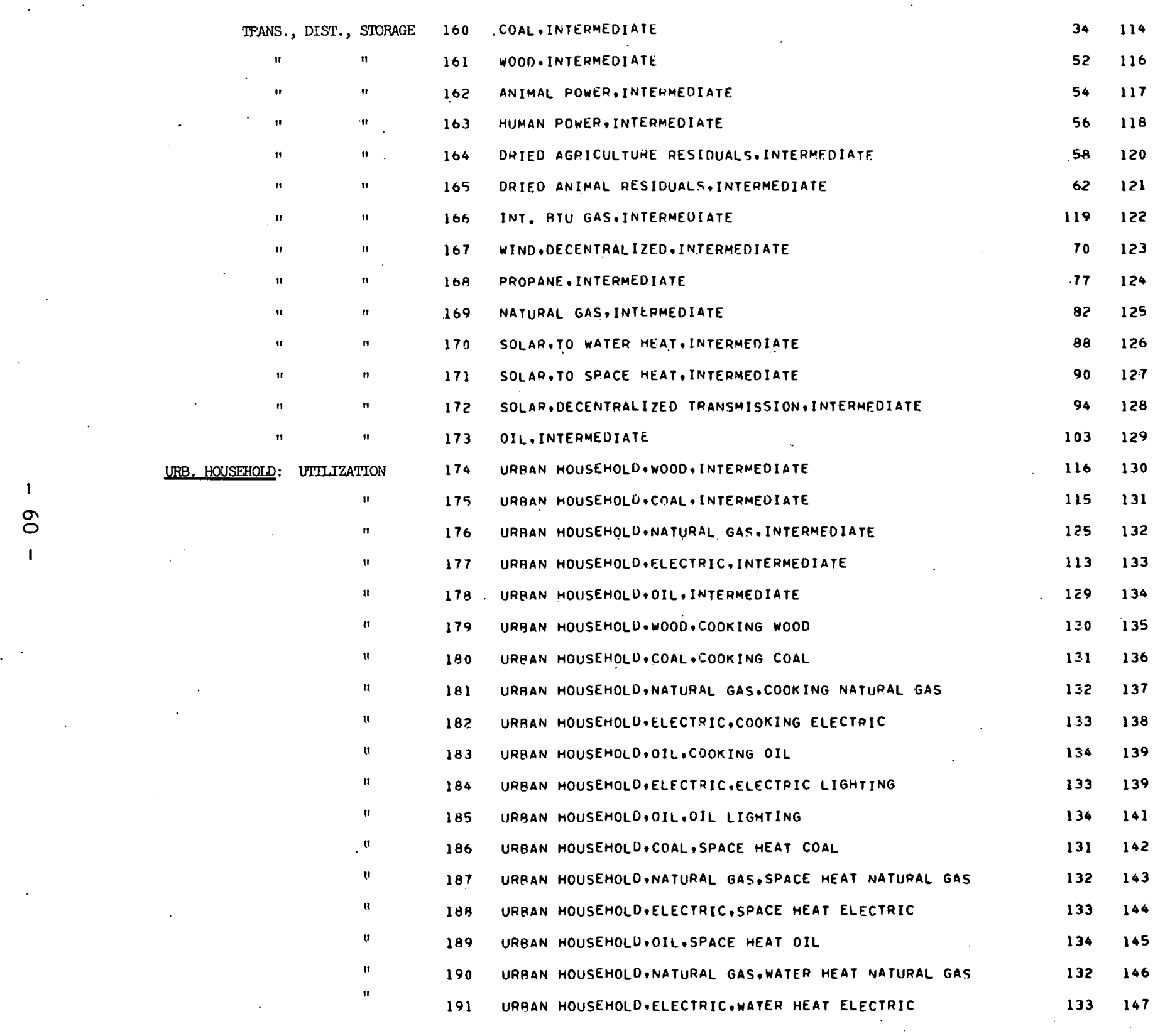


UREAN COMMERCIAL, COAL, SPACE HEAT COAL

URAAN COMMERCIAL. NATURAL GAS, WATER HEAT NATURAL GAS 


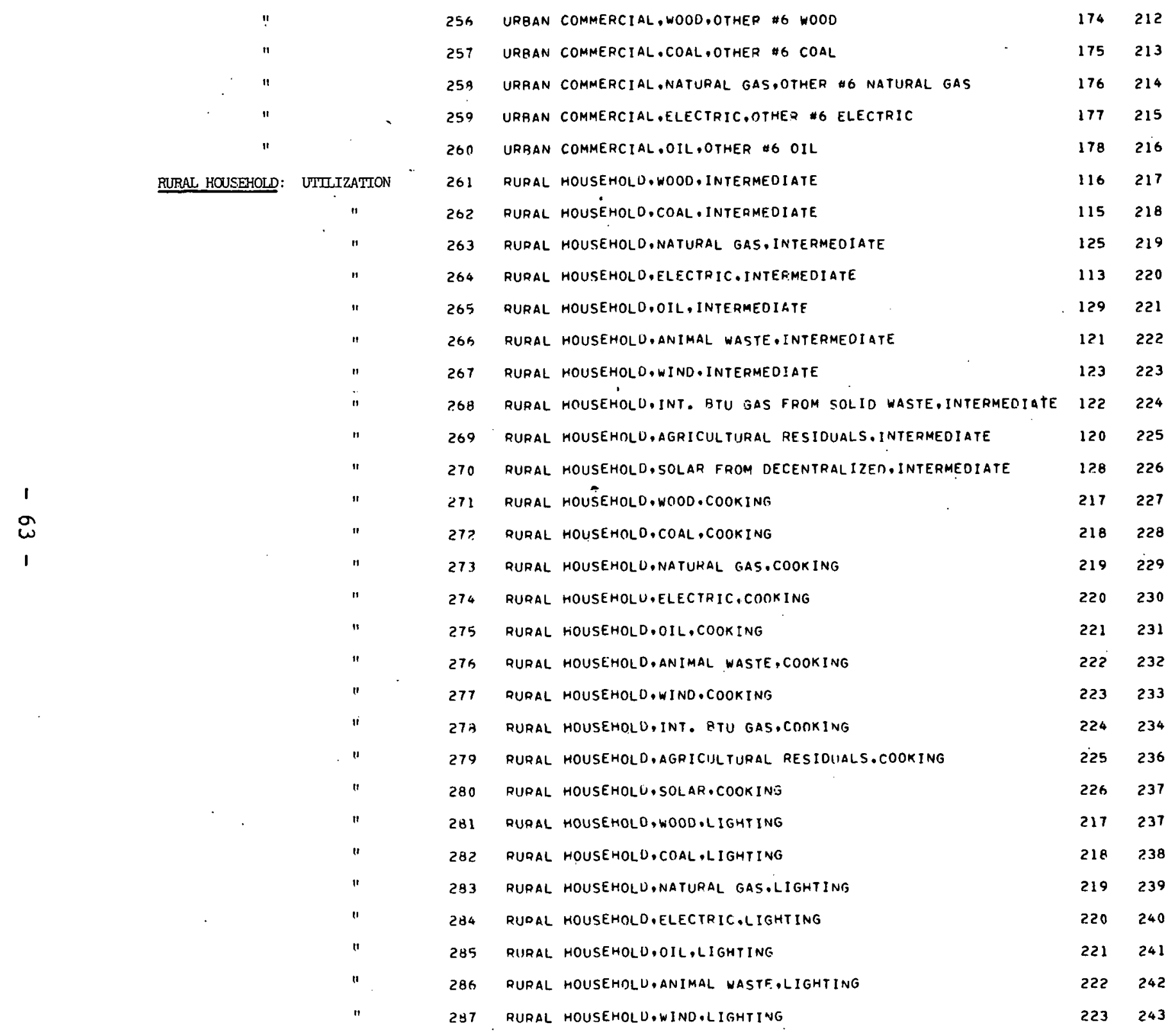




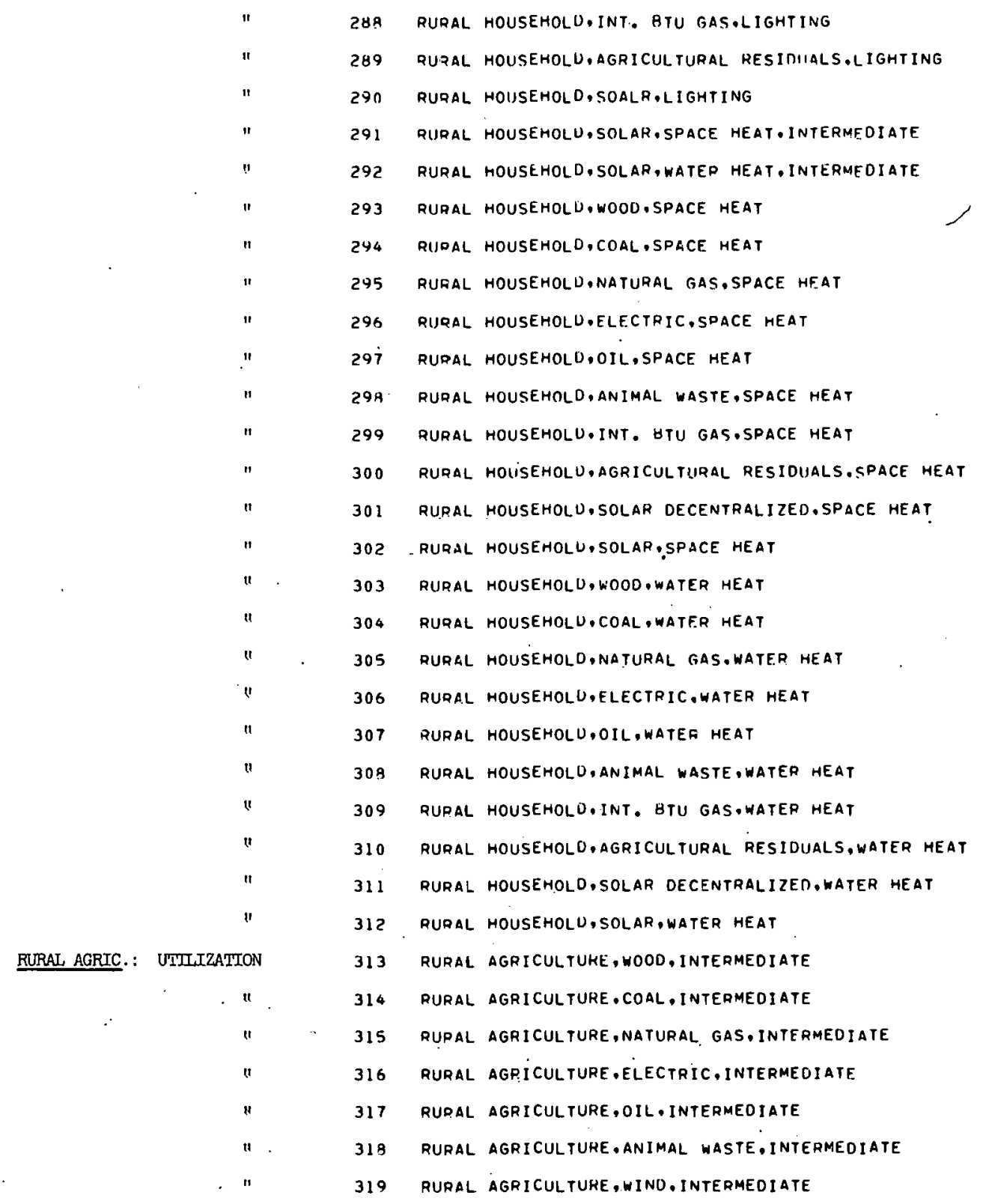




\section{RUPAL AGRICULTURE, SOLAR DECENTRALIZED. INTERMEDIATE}

RURAL AGRICULTURE, SOLAR, SPACE MEAT, INTERMEDIATE 
RUPAL, INT. GTU GAS,AGRICILLTIRE END IISE 2 
387 RUPAL,OIL,AGRICULTURE END USE 5

388 RURAL, ANIMAL WASTE, AGRICIJLTURE END USE 5

393 RUPAL,ANIMAL POWER, AGRICIJLTIJRE END USE 5

394 RURAL, HUMAN POWER.AGRICULTURE END USE 5 
419 RURAL SMALL INUUSTRY.SOLAR DECENTRALIZEM.AGPIC. PROCESSING 
480 MISC.RURAL, INT. BTU GAS, RIJPAL ENO USE 3 
INDUSTRY,OIL, INOUSTRY I

INDUSTRY, ELECTRIC, INDUSTRY 2

INDUSTRY, NATURAL GAS, INDUSTRY 2

INDISTRY, COAL, INDUSTRY 2

INDUSTRY, OIL, INOUSTRY

INDUSTRY, ELECTRIC, INOUSTRY 3

INDUSTRY, NATURAL GAS, INDUSTRY 3

INDUSTRY, COAL, INDUSTRY 3

INDUSTRY.OIL, INOUSTRY 3

INOUSTRY, ELECTRIC, INOUSTRY 4

INOUSTRY,NATURAL GAS, INDUSTRY 4

INOUSTRY, COAL, INDUSTRY 4

INOUSTRY,OIL, INDIISTRY 4

INDUSTRY, ELECTRIC, INDUSTRY 5

INDUSTRY, NATURAL GAS, INOUSTAY 5

INDUSTRY, COAL, INDUISTRY 5

INOUSTRY,DIL, INUUSTRY 5

INDUSTRY,ELECTRIC, INDUSTRY 5

INOUSTRY,NATURAL GAS,INDUSTRY 6

INDUSTRY, COAL, INDUSTPY 6

\section{INDUSTRY, OIL, INDUSTRY}

INDUSTRY, ELECTRIC, INOUSTRY ?

INDUSTRY, NATURAL GAS, INDUSTRY 7

INDUSTRY, COAL, INDUSTRY 7

INDUSTRY, OIL, INUUSTRY ?

INDUSTRY, ELECTTRIC, INDLISTRY 8

INDISTRY, NATIIRAL GAS, INDUSTRY 8

INDUSTRY, COAL, INCUSTRY 8 


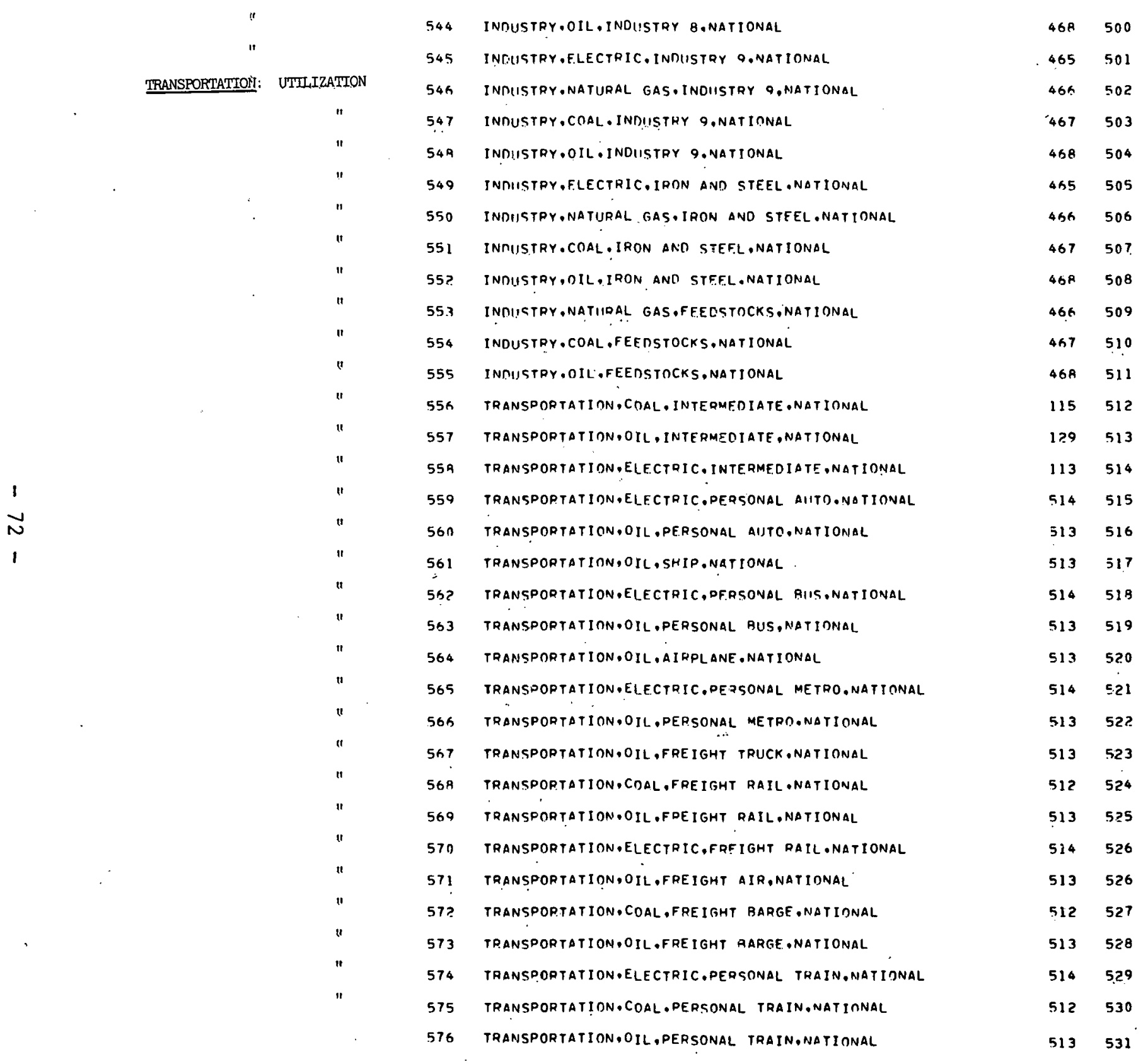


1. W. A. Sevian, "The Energy System Network Simulator (ESNS): General Description and Sample Analysis," BNL-50492 (Sept. 1975), Brookhaven National Laboratory. This document outlines the original concept of an energy system flows calculator.

2. The Reference Energy Systems approach to energy systems analysis for developing countries is described in Policy Analysis Division, National Center for Analysis of Energy Systems, "An Analytical Framework for the Assessment of Energy Resource and Technology Options for Developing Countries", BNL-50800 (February 1978), Brookhaven National Laboratory. 
